$1-1-1925$

\title{
Effects of Winter Rations on Pasture Gains of Two- Year-Old Steers
}

\author{
E.W. Sheets \\ E. A. Livesay \\ R. H. Tuckwiller
}

A. T. Stemple

Follow this and additional works at: https://researchrepository.wvu.edu/ wv_agricultural_and_forestry_experiment_station_bulletins

\section{Digital Commons Citation}

Sheets, E. W.; Livesay, E. A.; Tuckwiller, R. H.; and Stemple, A. T., "Effects of Winter Rations on Pasture Gains of Two-Year-Old Steers" (1925). West Virginia Agricultural and Forestry Experiment Station Bulletins. 191.

https://researchrepository.wvu.edu/wv_agricultural_and_forestry_experiment_station_bulletins/191 
West Virginia University Libraries 


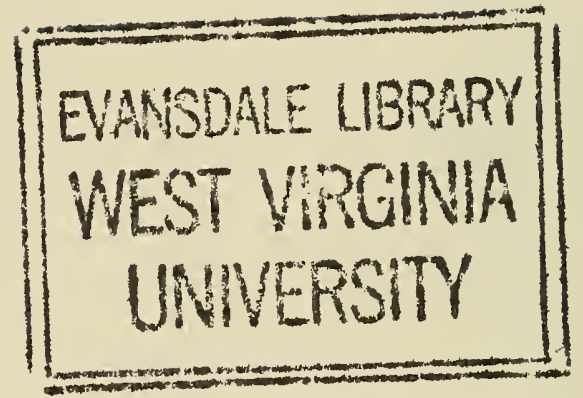


Restricted

\section{Circulation Only}

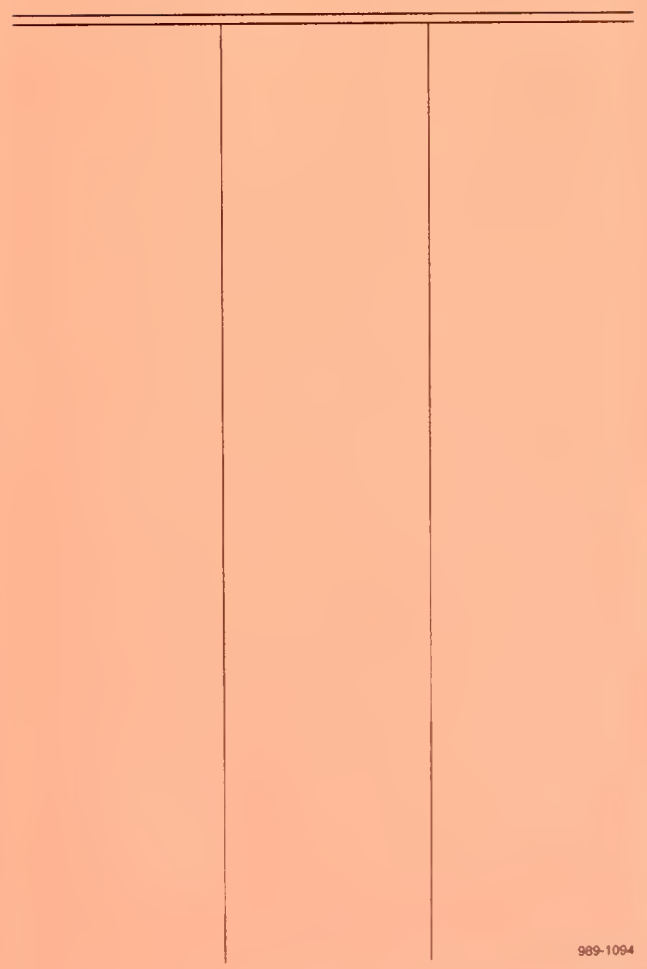





\section{Agricultural Experiment Station}

College of Agriculture, reatest Virginia Ennibersity

HENRY G. KNIGHT, Director

Morgantown

\section{EFFECTS OF WINTER RATIONS ON PASTURE GAINS OF TWO-YEAR-OLD STEERS}

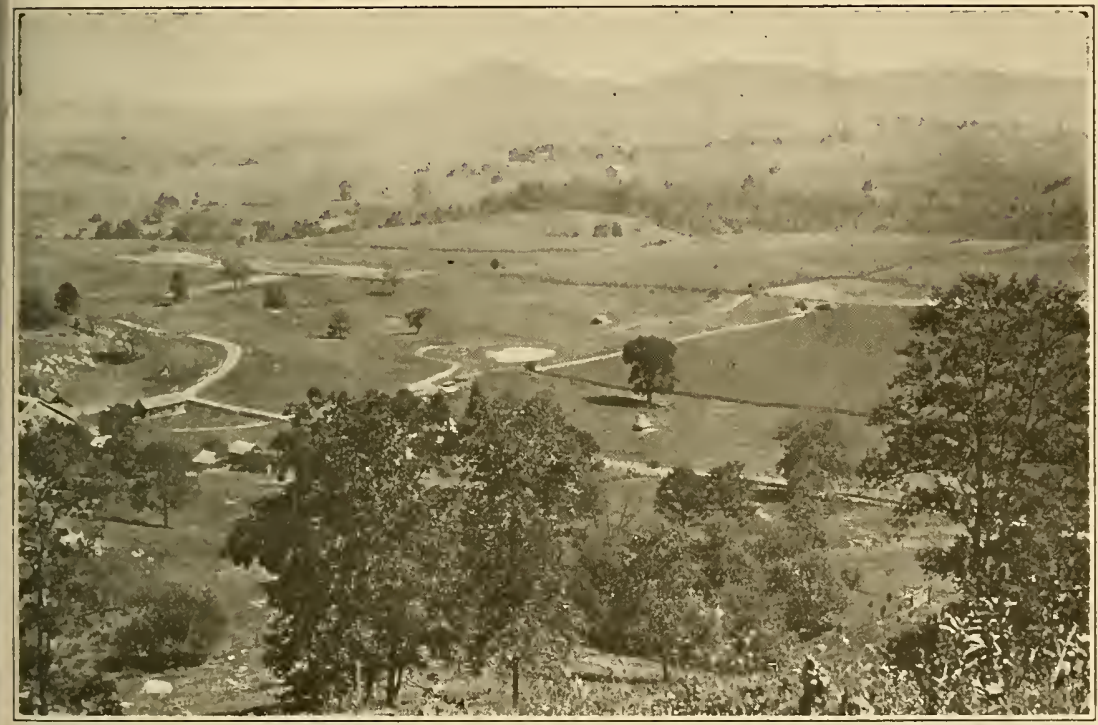

Looking From Muddy Creek Mountain Across a Branch of the Greenbrier Valley. The Steers Which Were Used as the Basis of This Study Were Fattened on a Pasture at the Foot of the Mountains Shown in the Dis. tance.

\section{By}

E. W. SHEETS, E. A. LIVESAY, R. H. TUCKWILLER, and A. T. STEMPLE

Publications of this Station will be mailed free to any citizen of West Virginia upon written application. Address Director of the West Virginia Agricultural Experiment Station, Morgantown, W. Va. 


\section{AGRICULTURAL EXPERIMENT STATION STAFF}

FRANK BUTLER TROTTER, A. M., LL. D. -....- President of the University GEORGE R. LYMAN, Ph. D. Dean of the College of Agriculture HENRY G. KNIGHT, Ph. D. WALTER C. SCHNOPP, B. S. Agr. JOHN C. JOHNSTON

Director of the Experiment Station

Agricultural Editor

\section{AGRONOMY}

R. J. Garber, Ph. D.

T. E. Odland, M. S.

Agronomist

T. C. McIlvaine, Ph. D. $\dot{\dagger}$ Assistant Agronomist

M. M. Hoover, M. S. Junior Agronomist H. K. Rowley, B. S. Agr. ***

Seed Analyst

\section{ANIMAL HUSBANDRY}

E. A. Livesay, .I. S. Animal Husbandman

Chas. V. Wilson, M. S.

Assistant Animal Husbandman

E. C. Stillweil, M. S.

Assistant Animal Husbardman

R. H. Tuckwiller, B. S. Agr.

Assistant Animal Husbazomian

\section{CHEMISTRY}

Henry G. Knight, Ph. D.

Chemist

R. B. Dustman, Ph. D.

Assistant Chemist

Chas. E. WVeakley, Jr., B. A.

T. B. Leith, B. A.*

Assistant Chemist

T. J. Cochlan. B. S

Assistant Chemist

Junior Cluemist

\section{DAIRY HUSBANDRY}

Ernest L. Anthuny, M. S. Agr.

Dairy Husbandman

H. O. Henderson, M. S. Agr.

Associate Daily Husbandman

Warren Gifford, B. S. Agr.市

G. M. Trout, M. S.

Junior Dairy Husbandman

Assistant in Dairy Husbandry

\section{ENTOMOLOGY}

L. M. Peairs, Ph. D. Entomologist IV. E. Rumsey, B. S.*"

\section{State Entomologist}

FARM ECONOMICS

A. J. Dadisman, Ph. D.

Paul A. Eke, Ph. D.

Farm Economist

Junior Farm Economist

F. D. Cornell, M. S.

Junior Farm Mechanician

IV. IV. Armentrout, M. S.

Junior Farm Economist

HOME ECONOMICS

Ruth Buchanan, Ph. D.

Home Economist

HORTICULTURE

M. J. Dorse: , Ph. D. ${ }^{* * *}$

H. L. Crane, M. S. Agr.

Horticulturist

Associate Horticulturist

H. E. Knowlton, Ph. D.

Associate Horticulturist

K. C. Westover, M. S. Agr.

Assistant Horticulturist

Ernest Angelo, M. S. Agr.

Junior Horticulturist

L. F. Sutton, B. S. Agr.t

Assistant Horticulturist

Troy M. Currence, B. S. Agr. ††

Assistant in Horticulture

PLANT PATHOLOGY

N. J. Giddings, Ph. D.

Anthony Berg, M. S.

Plant Pathologist

Assistant Plant Pathologist

L. H. Leonian, Ph. D.

E. C. Sherwood, M. S.

Assistant Plant Pathologist

Assistant Plant Pathologist

POULTRY HUSBANDRY

Horace Atwod, M. S. Agr.

Poultry Husbandman

E. P. Deatrick, Ph. D.

SOILS

Associate Soil Technologist

*In co-operation with the U. S. Department of Agriculture, Washington, D. C.

**In co-operation with the State Department of Agriculture, Charleston, W. Va.

***Resigned September 1, 1925.

$\ddagger$ In charge of the Reymann Memorial Farms, Wardensville, W. Va.

$\dagger$ In charge of the Maggie Sub-Station, Maggie, W. Va.

tion leave of absence. 
there are large areas of cut-over land. The farms vary in size from less than a hundred acres to more than a thousand acres. On most of the farms there is sufficient tillable land for the production of winter feed. Relatively little surplus grain is purchased.

Most of the cattle which go annually to eastern markets from this section are grass-fattened. The fact that most of them are finished for market on grass alone attests the value of the pastures, which consist largely of blue grass and white clover. The use of grain for finishing cattle is not general, although there are a few sections where the practice is followed, particularly in the valleys of some of the larger streams. Therefore, one of the principal beefproduction problems is to determine the best and most economical method of wintering the cattle, and the one that will enable them tc make the best possible use of the pasture the following summer. A common practice in this area has been to winter steers on dry feed, such as hay, corn stover, and wheat straw, and on corn silage to a less extent, in such a manner that the cattle often lose in weight. They are then pastured the following summer and sold from grass as stockers, feeders, or finished steers. There are some who hold that it is profitable to permit this loss of weight, which with older steers usually varies from 25 to 100 pounds. Others believe that cattle wintered on silage, or on a ration of which silage is a part, will not do well on grass the following summer.

The work was carried on for three years, in order to have an average of feeds, cattle, seasons, and other conditions tending to produce variation. A general outline of the experiment, including the rations used for the different lots of steers is given in Table 1.

\section{Kinds of Steers Used}

The steers used were long two-year-old grade Shorthorn, Hereford, and Aberdeen-Angus, raised in southern West Virginia. They were considered fair to good feeder steers and were quite uniform in quality and condition. They ranged in weight from 800 to 1,200 pounds and averaged 964 pounds at the beginning of the winter periods. 
TABLE 2.-Composition of Feeds Used, as Analyzed by the West Virginia Agricultural Experiment Station,* Compared With Average Analyses of Similar Feeds as Made by the United States Department of Agriculture.

\begin{tabular}{|c|c|c|c|c|c|c|c|}
\hline Feed & $\begin{array}{l}\text { Sources of } \\
\text { Analyses }\end{array}$ & 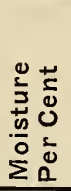 & 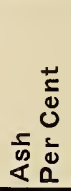 & 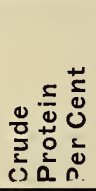 & 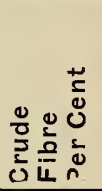 & 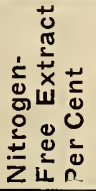 & 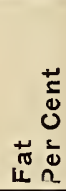 \\
\hline Corn silage & $\begin{array}{l}\text { W. Va. Exp. Sta. } \\
\text { U. S. Dept. Agr. }\end{array}$ & $\begin{array}{l}72.9 \\
70.9\end{array}$ & $\begin{array}{l}1.8 \\
1.4\end{array}$ & $\begin{array}{l}2.2 \\
2.4\end{array}$ & $\begin{array}{l}6.2 \\
6.9\end{array}$ & $\begin{array}{l}16.1 \\
17.5\end{array}$ & $\begin{array}{l}0.8 \\
0.9\end{array}$ \\
\hline Mixed hay & $\begin{array}{l}\text { W. Va. Exp. Sta. } \\
\text { U. S. Dept. Agr. }\end{array}$ & $\begin{array}{r}7.1 \\
12.7 \\
\end{array}$ & $\begin{array}{l}4.1 \\
6.2\end{array}$ & $\begin{array}{r}6.3 \\
10.2 \\
\end{array}$ & $\begin{array}{l}33.7 \\
26.2\end{array}$ & $\begin{array}{l}47.0 \\
41.7\end{array}$ & $\begin{array}{l}1 . \overline{8} \\
3.0\end{array}$ \\
\hline $\begin{array}{l}\text { Wheat } \\
\text { straw }\end{array}$ & $\begin{array}{l}\text { W. Va. Exp. Sta. } \\
\text { U. S. Dept. Agr. }\end{array}$ & $\begin{array}{l}6.9 \\
9.6\end{array}$ & $\begin{array}{l}3.3 \\
4.2\end{array}$ & $\begin{array}{l}3.6 \\
3.4\end{array}$ & $\begin{array}{l}41.6 \\
38.1\end{array}$ & $\begin{array}{l}43.4 \\
43.4\end{array}$ & $\begin{array}{l}1.2 \\
1.3\end{array}$ \\
\hline Ear corn & $\begin{array}{l}\text { W. Va. Exp. Sta. } \\
\text { U. S. Dept. Agr. }\end{array}$ & $\begin{array}{l}11.4 \\
15.6\end{array}$ & $\begin{array}{l}1.2 \\
1.5\end{array}$ & $\begin{array}{l}7.2 \\
8.3\end{array}$ & $\begin{array}{l}6.8 \\
6.8\end{array}$ & $\begin{array}{l}72.2 \\
64.4\end{array}$ & $\begin{array}{l}1.2 \\
3.4\end{array}$ \\
\hline $\begin{array}{l}\text { Cottonseed } \\
\text { meal }\end{array}$ & $\left|\begin{array}{l}\text { W. Va. Exp. Sta. } \\
\text { U. S. Dept. Agr. }{ }^{2}\end{array}\right|$ & $\begin{array}{l}7.2 \\
7.1\end{array}$ & $\begin{array}{l}6.4 \\
5.7\end{array}$ & $\begin{array}{l}42.1 \\
41.7\end{array}$ & $\begin{array}{r}8.0 \\
10.0\end{array}$ & $\begin{array}{l}29.0 \\
28.4\end{array}$ & $\begin{array}{l}7.3 \\
7.1\end{array}$ \\
\hline
\end{tabular}

${ }^{1}$ Calculated, using one-half red clover hay and one-half timothy hay.

${ }^{2}$ Choice cottonseed meal.

*Average analyses for the three years.

\section{Feeds Used}

Samples of each of the feeds used were taken at different times. during the winter periods and analyzed by the experiment station chem:sts. The averages of these analyses are given in Table 2. The average analyses of similar feeds, as compiled by the Bureau of Chem:stry, United States Department of Agriculture, are shown for comparison.

From the analyses it is evident that the feeds used were somewhat below the average in quality. The cottonseed meal was slightly: better than the average of that which is graded as "choice" by the Association of Feed Control Officials of the United States. The silage was made from dent corn.

A three-year rotation of crops, consisting of corn, wheat, and hay is practiced quite generally in southern West Virginia. Timothy is sown with the wheat in the fall and red clover is sown on the same field in the spring. This, as a rule, provides in the year following the wheat crop a mixed hay of approximately one-half tim- 
thy and one-half clover. The mixed hay used in this work was flataned in this manner, but it averaged abont two-thirds timothy and one-third clover.

\section{Character of Pasture}

Each year the steers were turned on to a rather hilly pasture of about three hundred acres. A small stream, which flows through the pasture, provided an abundance of fresh water throughout the summer.

The soil is of limestone formation. A good growth of blue grass with white clover was found on most parts of the pasture.

\section{OBJECTS AND PLAN OF THE EXPERIMENT}

This experiment had the following general problems in view: (1) To ascertain the effect of different wintering rations upon subsequent pasture gains; (2) To ascertain facts in regard to the effect of winter gains or losses on two-year-old steers upon subseguent pasture gains; and (3) To ascertain if cattle wintered on corn silage alone, or with the larger part of the at.un composed of corn silage, make satisfactory pasture gains.

Under normal climatic conditions there is rainfall enough to keep the grass growing thronghout the season.

\section{Method of Feeding and Handling the Steers}

In the fall before starting the steers on winter feed they were divided into lots of ten each. In making this division, care was taken to have the lots as nearly uniform as possible in quality,

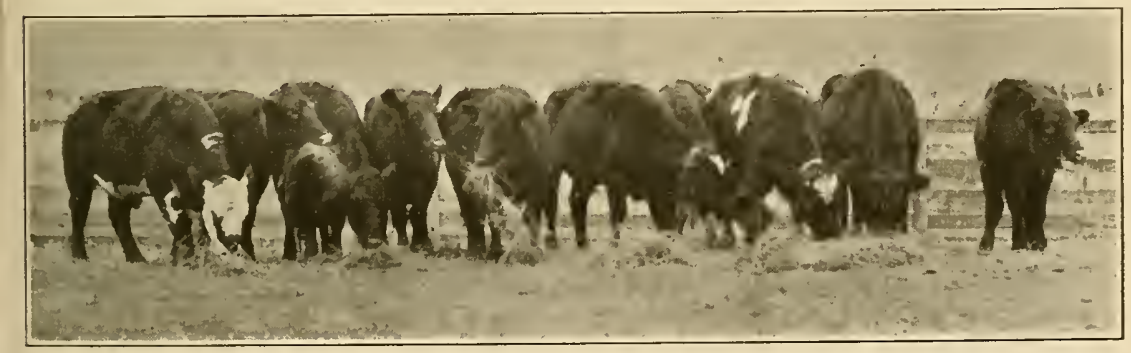

Lot 1 at the Beginning of the Third Year's Work; Winter Ration: Mixed Hay 15 Pounds, and Ear Corn 2 Pounds. 


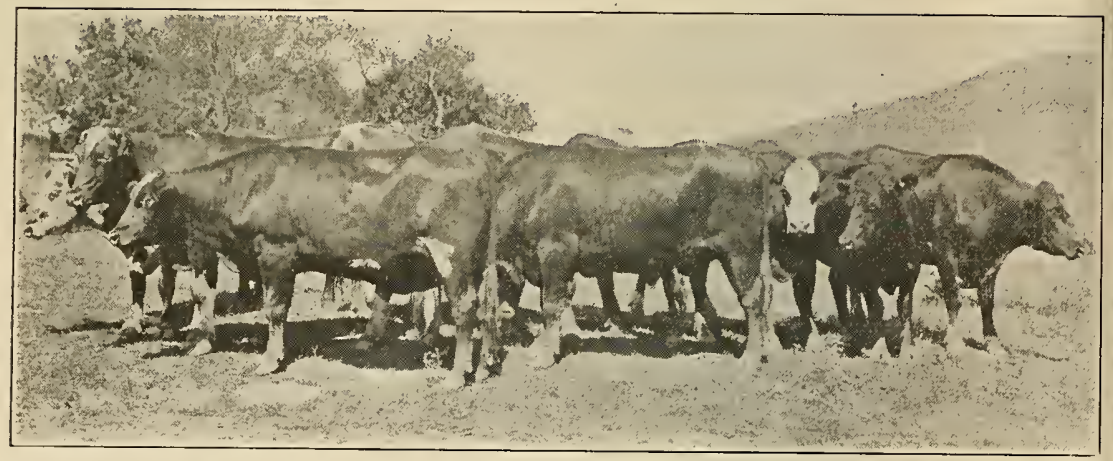

Lot 1 at the End of the Third Year's Work; Average Gain per Steer, 307 Pounds.

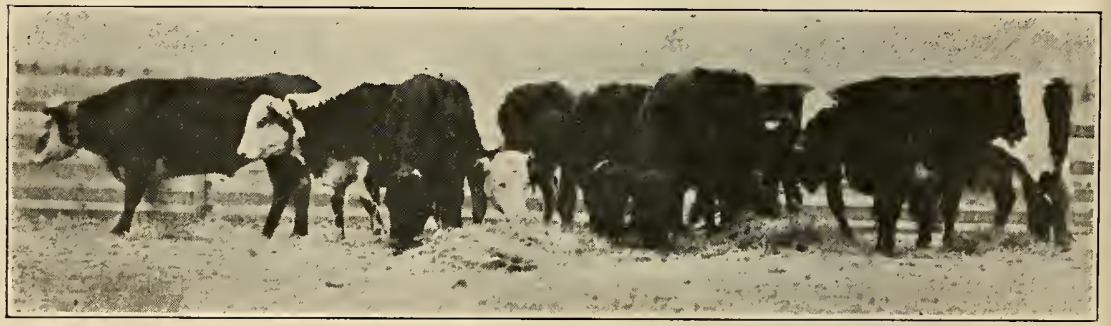

Lot 2 at the Beginning of the Third Year's Work: Winter Ration: Silage 28 Pounds.

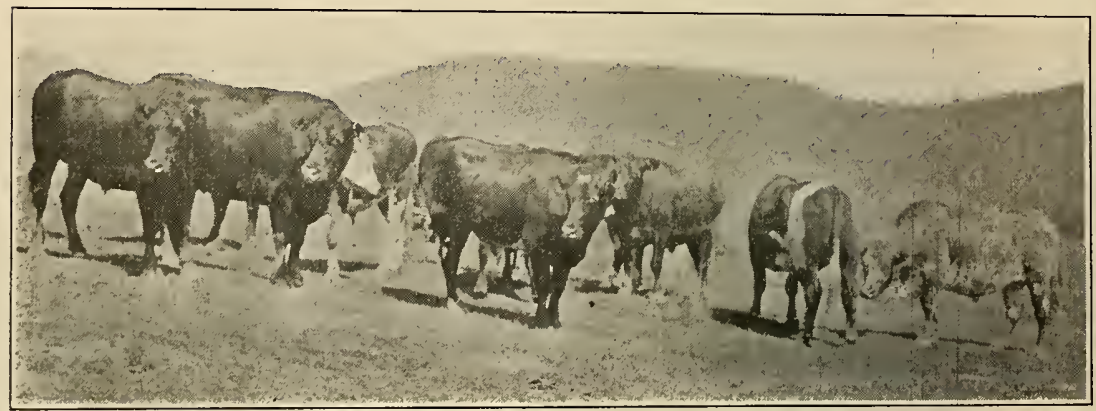

Lot 2 at the End of the Third Year's Work; Average Gain per Steer, 378 Pounds. 


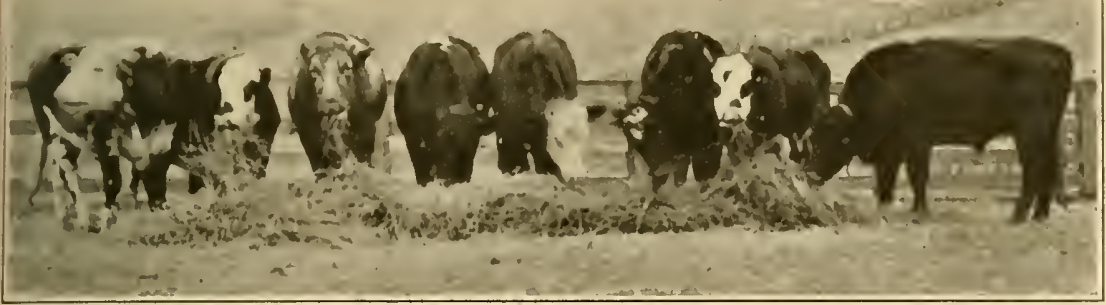

-ot 3 at the Beginning of the Third Year's Work; Winter Ration: Silage 36 Pounds.

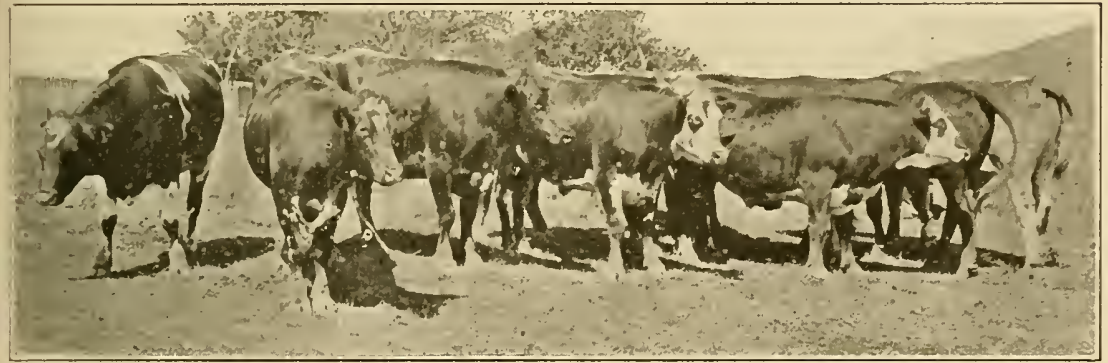

Lot 3 at the End of the Third Year's Work; Average Gain per Steer, 378 Pounds

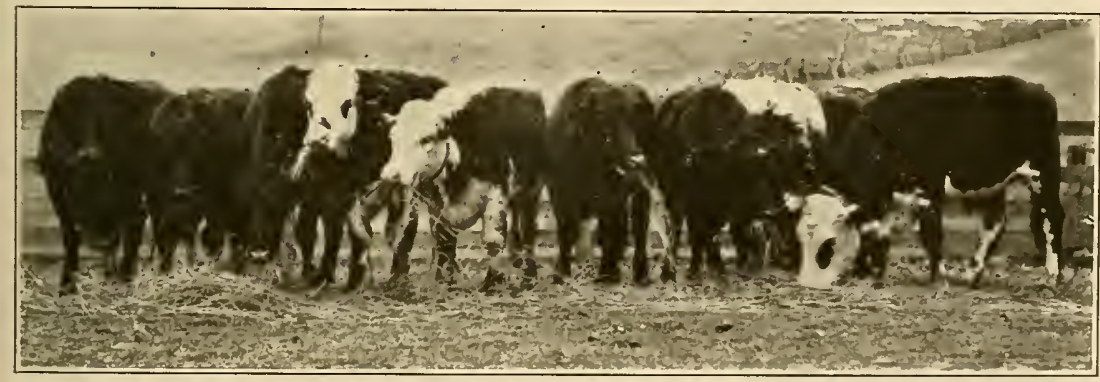

Lot 4 at the Beginning of the Third Year's Work; Winter Ration: Silage 30 Pounds, Cottonseed Meal 1.5 Pounds. 


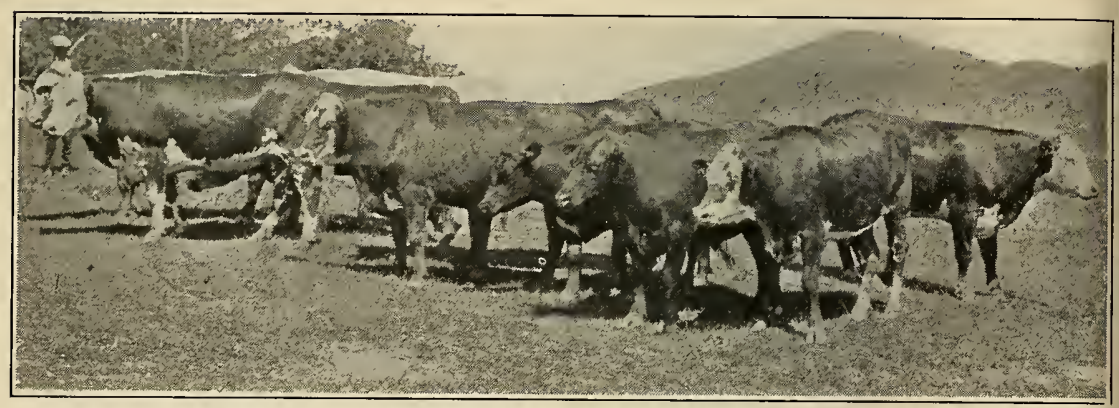

Lot 4 at the End of the Third Year's Work; Average Gain per Steer, 391 Pounds.

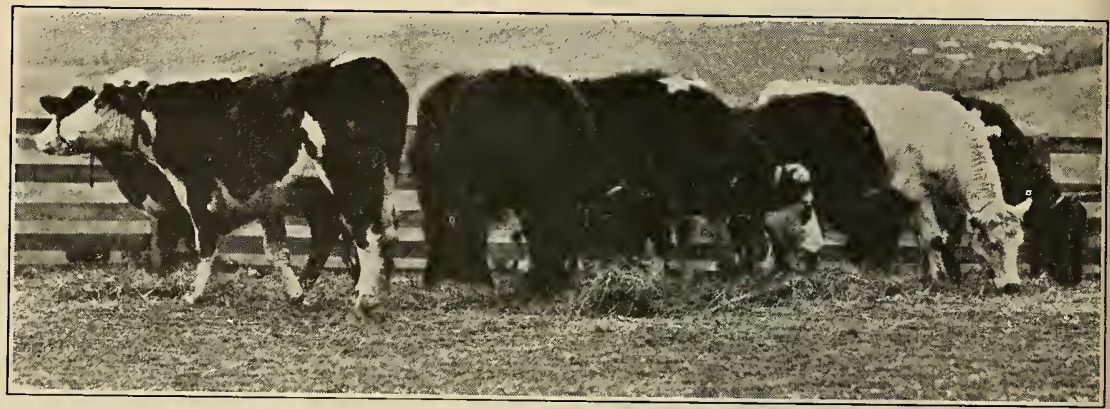

Lot 5 at the Beginning of the Third Year's Work; Winter Rations: Silage 25 Pounds, Straw 6 Pounds, and Cottonseed Meal 1 Pound.

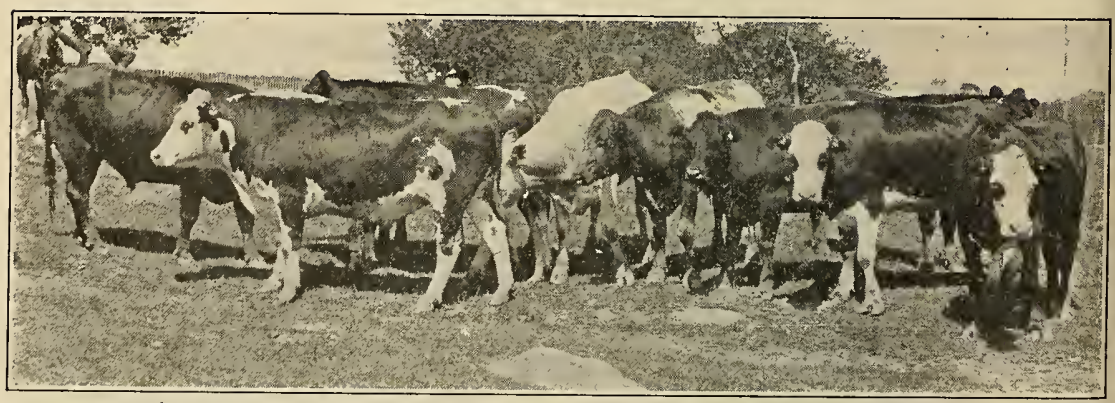

Lot 5 at the End of the Third Year's Work; Average Gain per Steer, 377 Fouricis.

breeding, size, and condition. The different lots were given the same amount of space in an open barn and were kept under cover all winter. Water was supplied in the pens at all times and salt was constantly available. The steers were fed twice a day. 
The feed, both concentrates and roughages, was carefully weighd at each feeding. The steers were weighed at the beginning and it the end of the winter feeding period, the weights being taken in each case three days in succession and the average taken as their nitial and final weights. They were also weighed once every 28 lays, in the morning after feeding. Neck straps and ear tags with numbers on them were used so that ready identification of each ndividual could be made and records accurately kept.

In the spring of each year, as soon as the grass was good enough, which was usually about April 25, the steers from all the lots were turned into the same pasture with no additional feed. Weights were taken once every 28 days during the first summer. Afterwards the practice was discontinued on account of the loss incident to driving heary steers from the pasture to the scales. During the second summer they were weighed only on the 62nd day and during the third summer only on the 44th day, and at the close of

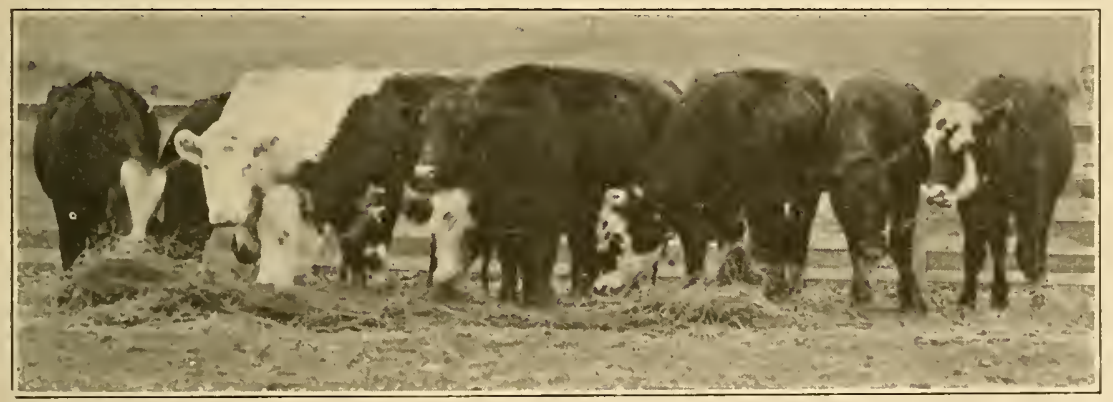

Lot 6 at the Beginning of the Third Year's Work; Winter Ration: Silage 25 Pounds and Mixed Hay 6 Pounds.

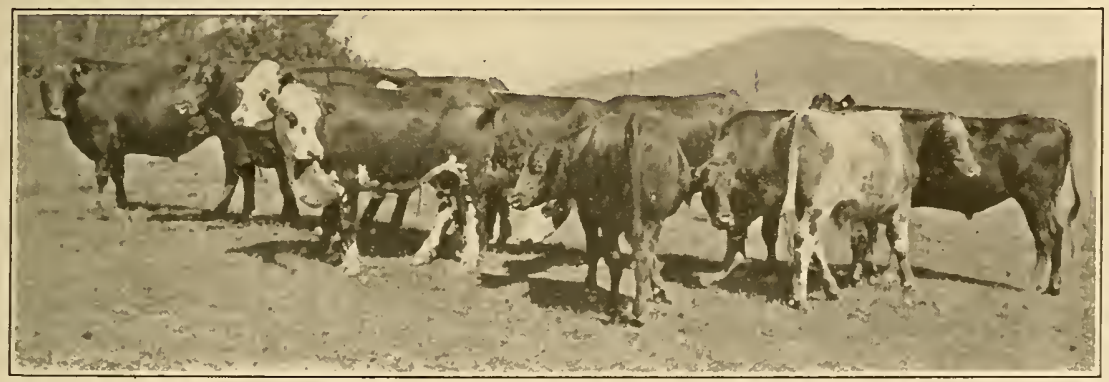

Lot 6 at the End of the Third Year's Work; Average Gain per Steer, 362 Pounds. 
the experiment. The final winter weights are the same as the initial weights when turned on grass.

\section{WINTER RATIONS AND THEIR INFLUENCE ON PASTURE GAINS}

\section{Quantity of Feed Consumed}

Table 3 shows the total amount of different feeds eaten by the various lots and the average daily ration per steer in each lot during each of the three winters. All lots, excepting Lot 2, were fed to make a small gain in weight. Lot 1 failed to gain in weight in the winter of 1921-22 on account of the poor quality of the mixed hay. The steers would not eat enough of it to maintain their weight. Lot 2 was fed to lose slightly in weight. This object was not attained the first year. The quantities of feed consumed daily were practically the same throughout the winter periods. Lot 3 was given practically as much silage as they would clean up.

As Table 4 shows, there was considerable variation in the quantities of dry matter and digestible nutrients contained in and the nutritive ratios of the rations as fed. The rations containing hay and straw were especially high in dry matter. The rations of silage alone were lowest in digestible protein while that containing 1.5 pounds of cottonseed meal was considerably the highest. The rations containing cottonseed meal had nutritive ratios, considerably narrower than the others. 
TABLE 3.-Average Total and Daily Rations per Steer During Three Winters.

\begin{tabular}{|c|c|c|c|c|c|c|c|c|}
\hline \multirow{2}{*}{$\begin{array}{l}\text { Winter } \\
\text { Feed }\end{array}$} & \multicolumn{4}{|c|}{$\begin{array}{c}\text { Total Feed per Steer in } \\
\text { Pounds }\end{array}$} & \multicolumn{4}{|c|}{$\begin{array}{c}\text { Daily Feed per Steer in } \\
\text { Pounds }\end{array}$} \\
\hline & $1919-20$ & $1920-2$ & $1921-22$ & Av'ge. & 1919-20 & $1920-21$ & 1921.22 & Av'ge. \\
\hline ot 1: & & & & & & & & \\
\hline Mixed hay & 2,540 & 2,403 & 1,860 & 2,268 & 20.0 & 19.9 & 15.0 & 18.3 \\
\hline Ear corn -....... & & & & 247 & 2.0 & 2.0 & 2.0 & 2.0 \\
\hline $\begin{array}{l}\text { ot 2: } \\
\text { Corn silage }\end{array}$ & 3,810 & 3,490 & 3,487 & 3,588 & 30.0 & 28.8 & 28.1 & 28.9 \\
\hline $\begin{array}{l}\text { ot } 3: \\
\text { Corn silage }\end{array}$ & 5,080 & 4,840 & 4,478 & 4,799 & 40.0 & 40.0 & 36.1 & 38.7 \\
\hline $\begin{array}{l}\text { ot } 4: \\
\text { Corn silage ............ } \\
\text { Cottonseed meal ... }\end{array}$ & $\begin{array}{r}3,810 \\
190\end{array}$ & $\begin{array}{r}3,490 \\
181\end{array}$ & $\begin{array}{r}3,683 \\
184\end{array}$ & $\begin{array}{r}3,661 \\
185\end{array}$ & $\begin{array}{r}30.0 \\
1.5\end{array}$ & $\begin{array}{r}28.8 \\
1.5\end{array}$ & $\begin{array}{r}29.7 \\
1.5\end{array}$ & 29.5 \\
\hline $\begin{array}{l}\text { ot } 5: \\
\text { Corn silage } \\
\text { Wheat straw } \\
\text { Cottonseed meal...... } \\
\end{array}$ & $\begin{array}{r}3,125 \\
734 \\
127 \\
\end{array}$ & $\begin{array}{r}3,025 \\
698 \\
121 \\
\end{array}$ & $\begin{array}{r}3,069 \\
736 \\
123 \\
\end{array}$ & $\begin{array}{r}3,076 \\
725 \\
124 \\
\end{array}$ & $\begin{array}{r}25.0 \\
5.8 \\
1.0 \\
\end{array}$ & $\begin{array}{r}25.0 \\
5.8 \\
1.0\end{array}$ & $\begin{array}{r}24.7 \\
5.9 \\
1.0\end{array}$ & $\begin{array}{r}24.8 \\
5.8 \\
1.0 \\
\end{array}$ \\
\hline $\begin{array}{l}\text { ot } 6: \\
\text { Corn silage .... } \\
\text { Mixed hay ..... }\end{array}$ & $\begin{array}{l}3,125 \\
1,016\end{array}$ & $\begin{array}{r}3,025 \\
968\end{array}$ & $\begin{array}{r}3,069 \\
749\end{array}$ & $\begin{array}{r}3,073 \\
911\end{array}$ & $\begin{array}{r}25.0 \\
8.0\end{array}$ & $\begin{array}{r}25.0 \\
8.0\end{array}$ & $\begin{array}{r}24.7 \\
6.0\end{array}$ & $\begin{array}{r}24.8 \\
7.3\end{array}$ \\
\hline
\end{tabular}

TABLE 4.-Quantities of Dry Matter, Digestible Nutrients, and Nutritive Ratios of the Rations.

\begin{tabular}{|c|c|c|c|c|c|c|}
\hline \multirow[b]{2}{*}{ है } & \multirow{2}{*}{$\begin{array}{l}\text { Average } \\
\text { Winter Ration per Steer } \\
\text { During Three Winters }\end{array}$} & \multirow{2}{*}{$\begin{array}{l}\text { Pounds } \\
\text { Dry } \\
\text { Matter }\end{array}$} & \multicolumn{2}{|c|}{$\begin{array}{c}\text { Pounds Digestible } \\
\text { Nutrients }\end{array}$} & \multirow[b]{2}{*}{$\begin{array}{l}\text { Nutri- } \\
\text { tive } \\
\text { Ratio }\end{array}$} & \multirow{2}{*}{$\begin{array}{c}\text { Feed } \\
\text { per } \\
1,000 \\
\text { Pounds } \\
\text { Live- } \\
\text { weight }\end{array}$} \\
\hline & & & Protein & $\begin{array}{c}\text { Carbo- } \\
\text { hydrate } \\
\text { Equivo- } \\
\text { lent }^{1}\end{array}$ & & \\
\hline \multirow[t]{3}{*}{1} & Mixed hay (18.3 pounds) & 17.0 & 0.63 & 9.08 & & 19.0 \\
\hline & Ear corn $(2.0$ pounds & 1.8 & 0.07 & 1.38 & & 2.1 \\
\hline & Total & 18.8 & 0.70 & 10.46 & $1: 14.9$ & - \\
\hline 2 & |Corn silage (28.9 pounds)........ & 7.8 & 0.37 & 4.99 & $1: 13.6$ & 30.1 \\
\hline 3 & |Corn silage (38.7 pounds)........ & 10.5 & 0.49 & 6.67 & $1: 13.6$ & 40.1 \\
\hline \multirow[t]{3}{*}{4} & Corn silage (29.5 pounds) ......... & 8.0 & 0.38 & 5.09 & & 30.6 \\
\hline & Cottonseed meal (1.5 pounds) & 1.4 & 0.53 & 0.61 & & 1.6 \\
\hline & Total & 9.4 & 0.91 & 5.70 & $1: 6.3$ & ...... \\
\hline \multirow[t]{4}{*}{5} & Corn silage ( 24.8 pounds). & 6.7 & 0.32 & 4.28 & & 25.7 \\
\hline & Wheat straw ( 5.8 pounds) & 5.4 & 0.02 & 2.26 & $\ldots$ & 6.0 \\
\hline & Cottonseed meal ( 1.0 pounds) & 0.9 & 0.35 & 0.41 & & 1.0 \\
\hline & Total..... & 13.0 & 0.69 & 6.97 & $1: 10.1$ & ....... \\
\hline \multirow[t]{3}{*}{6} & Corn silage $(24.8$ pounds $) .. . . . .$. & 6.7 & 0.32 & 4.28 & ............. & 25.7 \\
\hline & Mixed hay (7.3 pounds) & 6.8 & 0.25 & 3.62 & & 7.6 \\
\hline & Total............ & 13.5 & 0.57 & 7.92 & $1: 13.9$ & $\cdots$ \\
\hline
\end{tabular}
1The carbohyc
the digestible fat.

abased on the initial weights of the steers.

\section{Gains During Winter and Summer}

The initial spring and final weights and the gains and losses in weight during each of the three years are shown in Table 5. 
TABLE 5.-Average Total and Daily Gains During Winter and Summer in Pounds.*

\begin{tabular}{|c|c|c|c|c|c|c|c|c|c|c|c|}
\hline \multirow[t]{2}{*}{$\frac{\overline{0}}{\xi}$} & \multirow[t]{2}{*}{$\begin{array}{l}\text { Winter } \\
\text { Feed }\end{array}$} & \multirow[t]{2}{*}{ Season } & \multirow{2}{*}{ 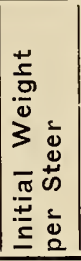 } & \multirow{2}{*}{ 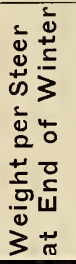 } & \multicolumn{2}{|c|}{$\begin{array}{l}\text { Winter } \\
\text { Gain } \\
\text { or Loss } \\
\text { per Steer }\end{array}$} & \multirow{2}{*}{ 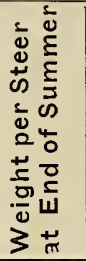 } & \multicolumn{2}{|c|}{$\begin{array}{l}\text { Summer } \\
\text { Gain } \\
\text { per Steer }\end{array}$} & \multicolumn{2}{|c|}{$\begin{array}{l}\text { Winter } \\
\text { and } \\
\text { Summer } \\
\text { Gain per } \\
\text { Steer }\end{array}$} \\
\hline & & & & & Total & Daily & & Total & Daily & Total & Daily \\
\hline \multirow[t]{4}{*}{1} & \multirow{4}{*}{$\begin{array}{l}\text { Mixed hay } \\
\text { and corn }\end{array}$} & & 927 & 962 & 35 & 0.28 & 1,269 & 307 & 2.26 & 342 & 1.30 \\
\hline & & & 981 & 1,036 & 55 & 0.45 & 1,321 & 285 & 2.23 & 340 & 1.3 \\
\hline & & & 980 & 943 & -37 & -0.30 & 1,287 & 344 & 2.44 & 307 & 1.16 \\
\hline & & Ave & 962 & 980 & $\begin{array}{r}18 \\
\pm 6.9 \\
\end{array}$ & 0.14 & 1,292 & $\begin{array}{r}312 \\
\pm 5.9 \\
\end{array}$ & 2.31 & $\begin{array}{r}330 \\
\pm 6.6 \\
\end{array}$ & 1.27 \\
\hline \multirow{4}{*}{2} & \multirow{4}{*}{$\begin{array}{l}\text { Corn } \\
\text { silage }\end{array}$} & & 913 & 950 & 37 & 0.29 & 1,236 & 286 & 2.10 & 323 & 1.23 \\
\hline & & & 981 & 927 & -54 & -0.45 & 1,290 & 363 & 2.84 & 309 & 1.2 \\
\hline & & & 983 & 977 & -6 & -0.05 & 1,361 & 384 & 2.72 & 378 & 1.43 \\
\hline & & $\mathrm{Av}$ & 961 & 952 & $\begin{array}{r}-9 \\
\pm 8.0 \\
\end{array}$ & -0.07 & 1,298 & $\begin{array}{r}346 \\
\pm 8.1 \\
\end{array}$ & 2.56 & $\begin{array}{r}337 \\
\pm 7.2 \\
\end{array}$ & 1.30 \\
\hline \multirow{4}{*}{3} & \multirow{4}{*}{$\begin{array}{l}\text { Corn } \\
\text { silage }\end{array}$} & & 928 & 1,007 & 79 & 0.62 & 1,246 & 239 & 1.76 & 318 & 1.21 \\
\hline & & & 987 & 1,033 & 46 & 0. & 1,3 & 30 & 2.38 & 351 & 1. \\
\hline & & & 981 & 1,053 & 72 & 0.58 & 1,359 & 306 & 2.17 & 378 & 1.43 \\
\hline & & ge & 965 & 1,031 & $\begin{array}{r}66 \\
\pm 6.9 \\
\end{array}$ & 0.53 & 1,314 & $\begin{array}{r}283 \\
\pm 7.3 \\
\end{array}$ & 2.10 & $\begin{array}{r}349 \\
\pm 8.1 \\
\end{array}$ & 1.35 \\
\hline \multirow{4}{*}{4} & \multirow{4}{*}{$\begin{array}{l}\text { Corn } \\
\text { silage and } \\
\text { cotton- } \\
\text { seed } \\
\text { meal }\end{array}$} & & 927 & 994 & 67 & 0.53 & 1,291 & 297 & 2.18 & 364 & 1.38 \\
\hline & & & 983 & 998 & 15 & 0.1 & 1,314 & 316 & 2.47 & 331 & 1.33 \\
\hline & & & 982 & 1,051 & 6 & 0.56 & 1,373 & 322 & 2.28 & 391 & 1.48 \\
\hline & & $\mathrm{Av}$ & 964 & 1,014 & $\begin{array}{r}50 \\
+6.4 \\
\end{array}$ & 0.40 & 1,326 & $\begin{array}{r}312 \\
\pm 6.9 \\
\end{array}$ & 2.31 & $\begin{array}{r}362 \\
\pm 6.6 \\
\end{array}$ & 1.40 \\
\hline \multirow{4}{*}{$b$} & \multirow{4}{*}{$\begin{array}{l}\text { Corn silage, } \\
\text { wheat } \\
\text { straw, and } \\
\text { cotton- } \\
\text { seed meal }\end{array}$} & & 927 & 1,020 & 93 & 0.73 & 1,270 & 250 & 1.84 & 343 & 1.30 \\
\hline & & & 98 & 1,049 & 62 & 0.51 & 1,294 & 245 & 1.91 & 307 & 1.23 \\
\hline & & 22 & 988 & 1,085 & 97 & 0.78 & 1,365 & 280 & 1.99 & 377 & 1.42 \\
\hline & & Average & 966 & 1,052 & $\begin{array}{r}86 \\
+4.6 \\
\end{array}$ & 0.69 & 1,310 & $\begin{array}{r}258 \\
\pm 5.7 \\
\end{array}$ & 1.91 & $\begin{array}{r}344 \\
\pm 6.7 \\
\end{array}$ & 1.33 \\
\hline \multirow[t]{4}{*}{ b } & \multirow{4}{*}{$\begin{array}{l}\text { Corn } \\
\text { silage } \\
\text { and } \\
\text { mixed } \\
\text { hay }\end{array}$} & $1919-20$ & 928 & 991 & 63 & 0.50 & 1,264 & 273 & 2.01 & 336 & 1.28 \\
\hline & & $0-21$ & 984 & 1,052 & 68 & 0.56 & 1,295 & 243 & 1.90 & 311 & 1.25 \\
\hline & & 1921-22 & 982 & 1,028 & 46 & 0.37 & 1,344 & 316 & 2.24 & 362 & 1.37 \\
\hline & & Average & 965 & 1,024 & $\begin{array}{r}59 \\
\pm 4.9 \\
\end{array}$ & 0.48 & 1,301 & $\begin{array}{r}277 \\
\pm 7.2\end{array}$ & 2.05 & $\begin{array}{r}336 \\
\pm 6.1\end{array}$ & 1.30 \\
\hline
\end{tabular}

*On account of dropping fractions in the average weights of the steers as given in ihis table, one cannot always add the weights or gains for the 3 years, divide hy 3 , and obtain the average given. In no case is there more than one pound of difference.

\section{Diagrams of Gains and Losses}

The seven charts, Figures 2, 3, 4, 5, 6, 7, and 8 , show the gains and losses of the steers by 28-day periods, except as noted under "Method of Feeding and Handling the Steers," pages 7, 10, and 11. The first six show the effects of the six rations under comparison for the three years they were used, one chart being used for each ration. The seventh chart (Figure 8 ) shows the average gains for three years for each of the six rations. 
AVERAGE LENGTH OF FEEDING PERIOD

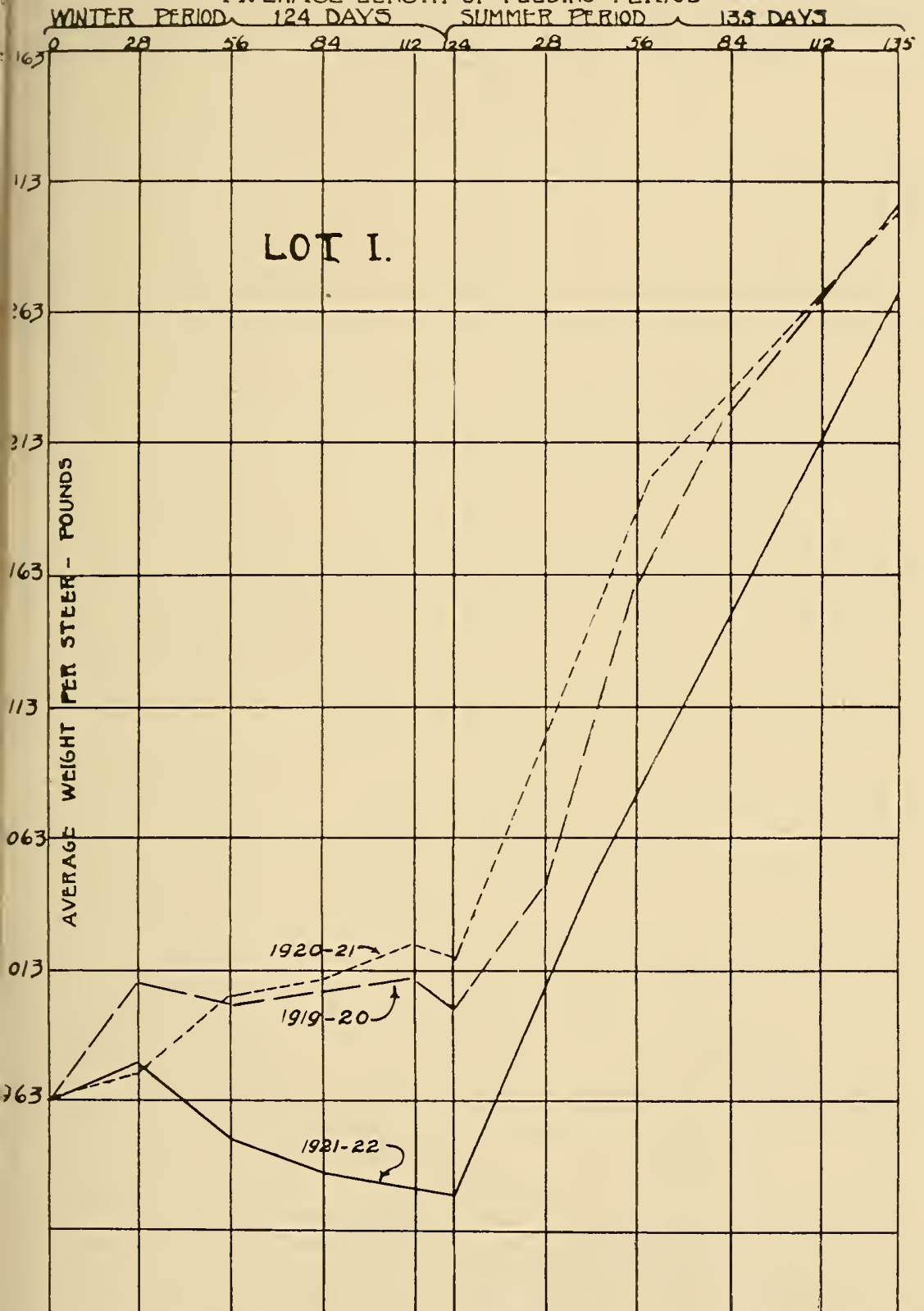

DEC25 JAN.2Z FED19 MAR.19 APR/6 APR28 MAY26 JUNE23 JULYI ALG.18 SEPTNO

Fig. 2.-Annual Results of Winter and Summer (Grass) Feeding for Lot 1. These Steers Were Fed the Following Average Ration During the Winter: Mixed Hay 18.3 Pounds and Ear Corn 2 Pounds. 
AVERAGE LENGTH OF FEEDING PERIOD

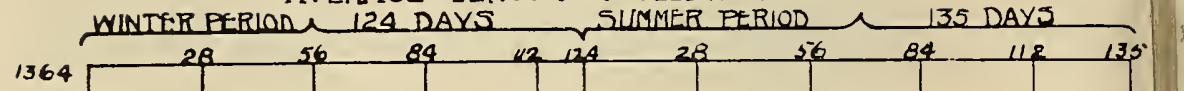

1314

1264

$2 / 4$

164

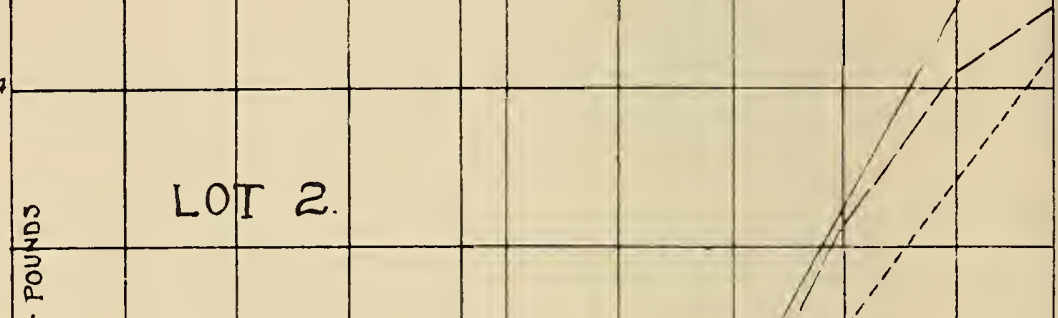

$1 / 14$

落

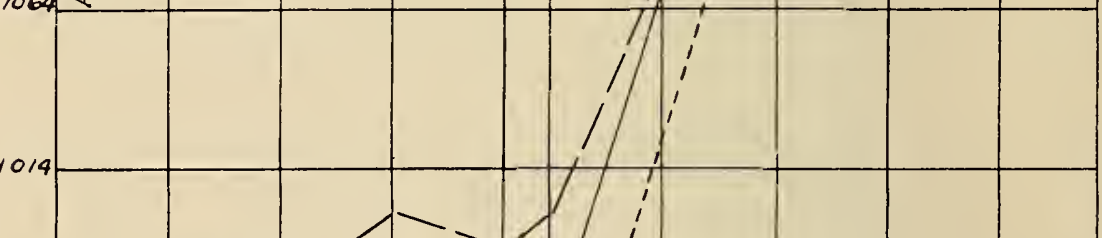

10 


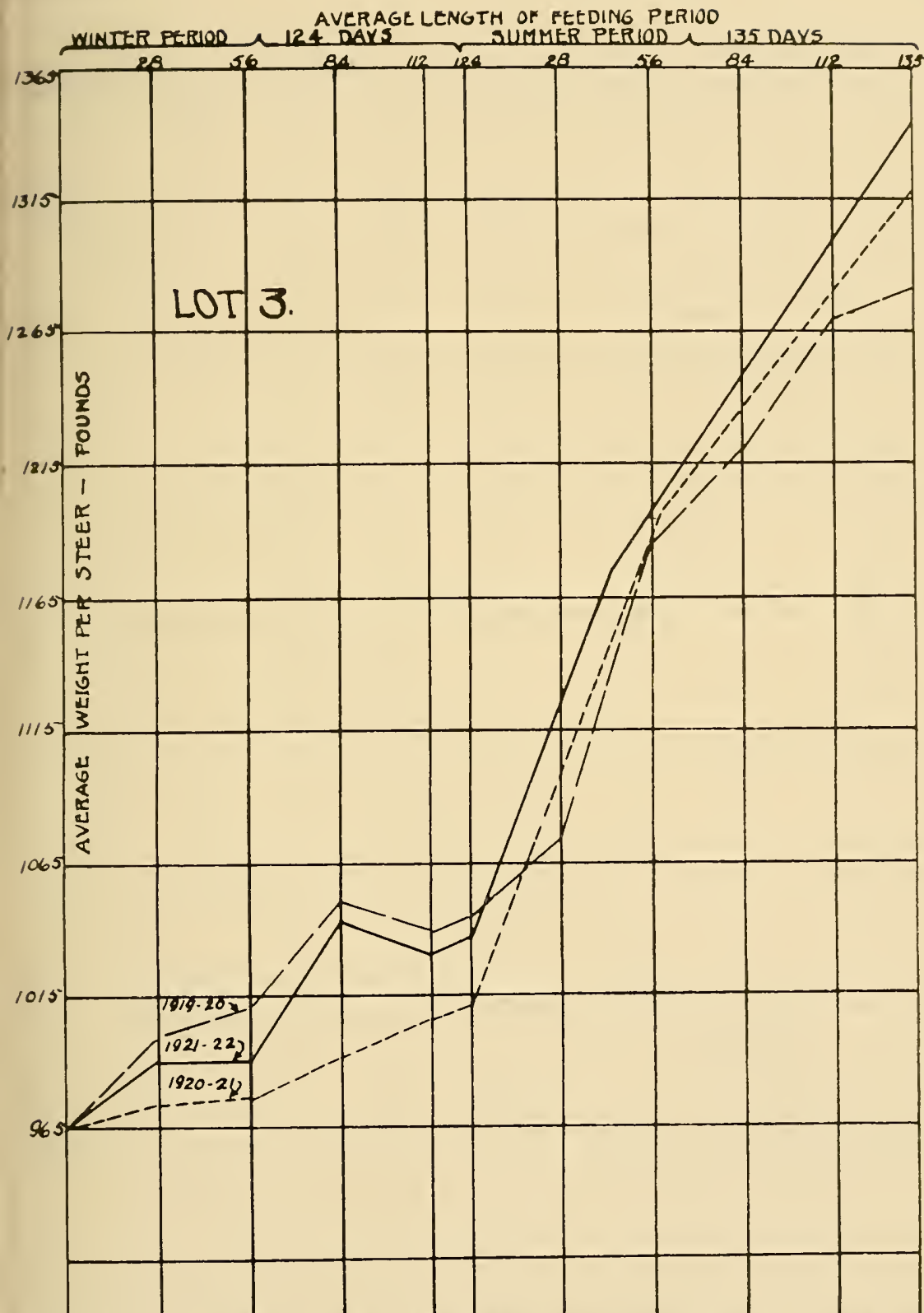

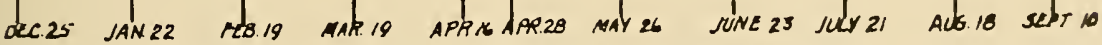

Fig. 4.-Annual Results of Winter and Summer (Grass) Feeding for Lot 3. These Steers Were Fed the Following Average Ration During the Winter: Corn Silage 38.7 Pounds. 
AVERAGE LENGTH OF FEEDING PERIOD

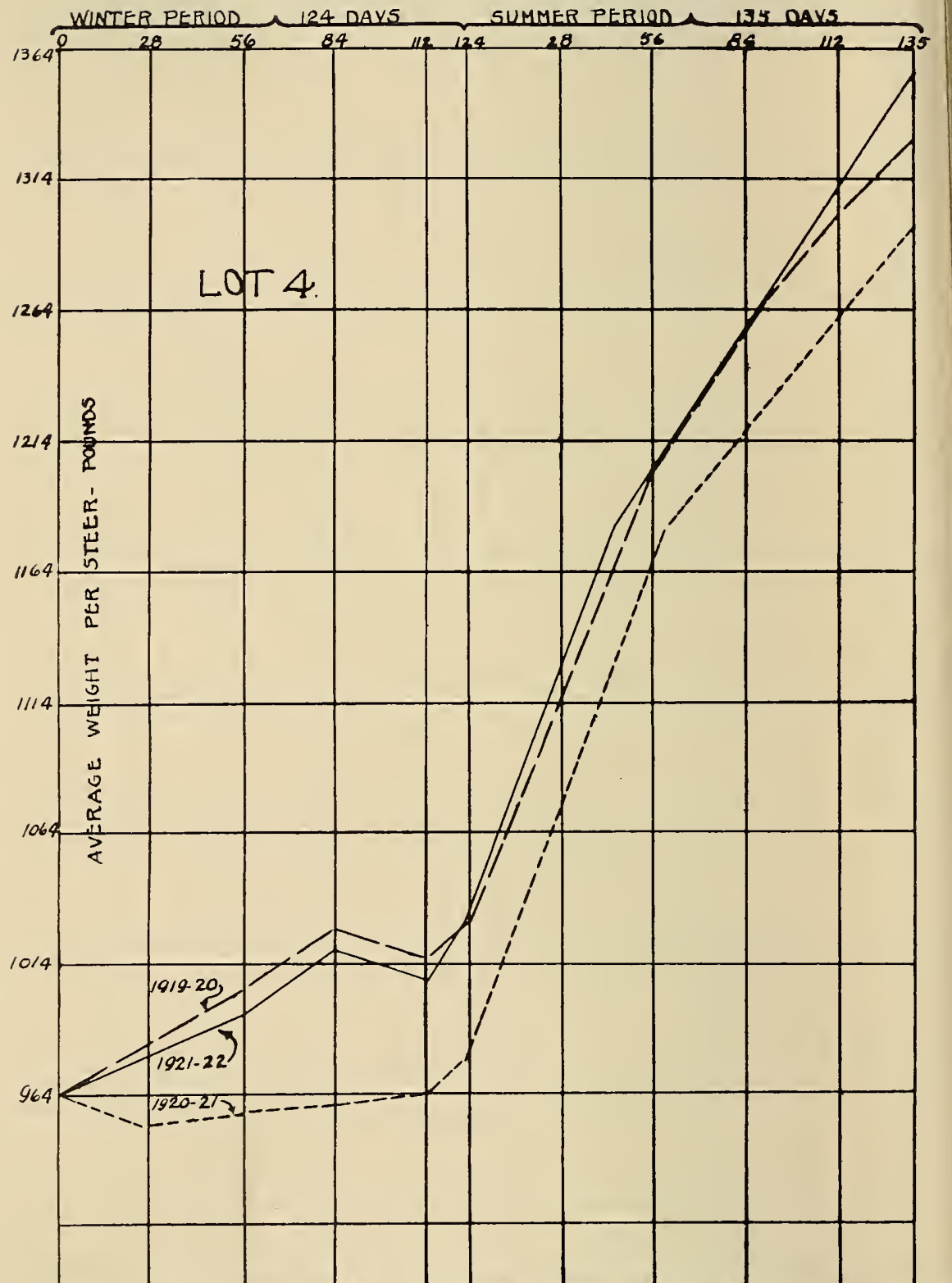

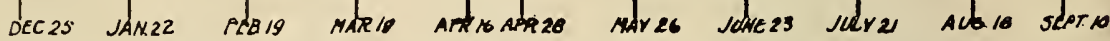

- Fig. 5.-Annual Results of Winter and Summer (Grass) Feeding for Lot 4. These Steers Were Fed the Following Average Ration During the Winter: Corn Silage 29.5 Pounds and Cottonseed Meal 1.5 Pounds. 
AVERAGE LENGTH OF FEEDING PERIOD

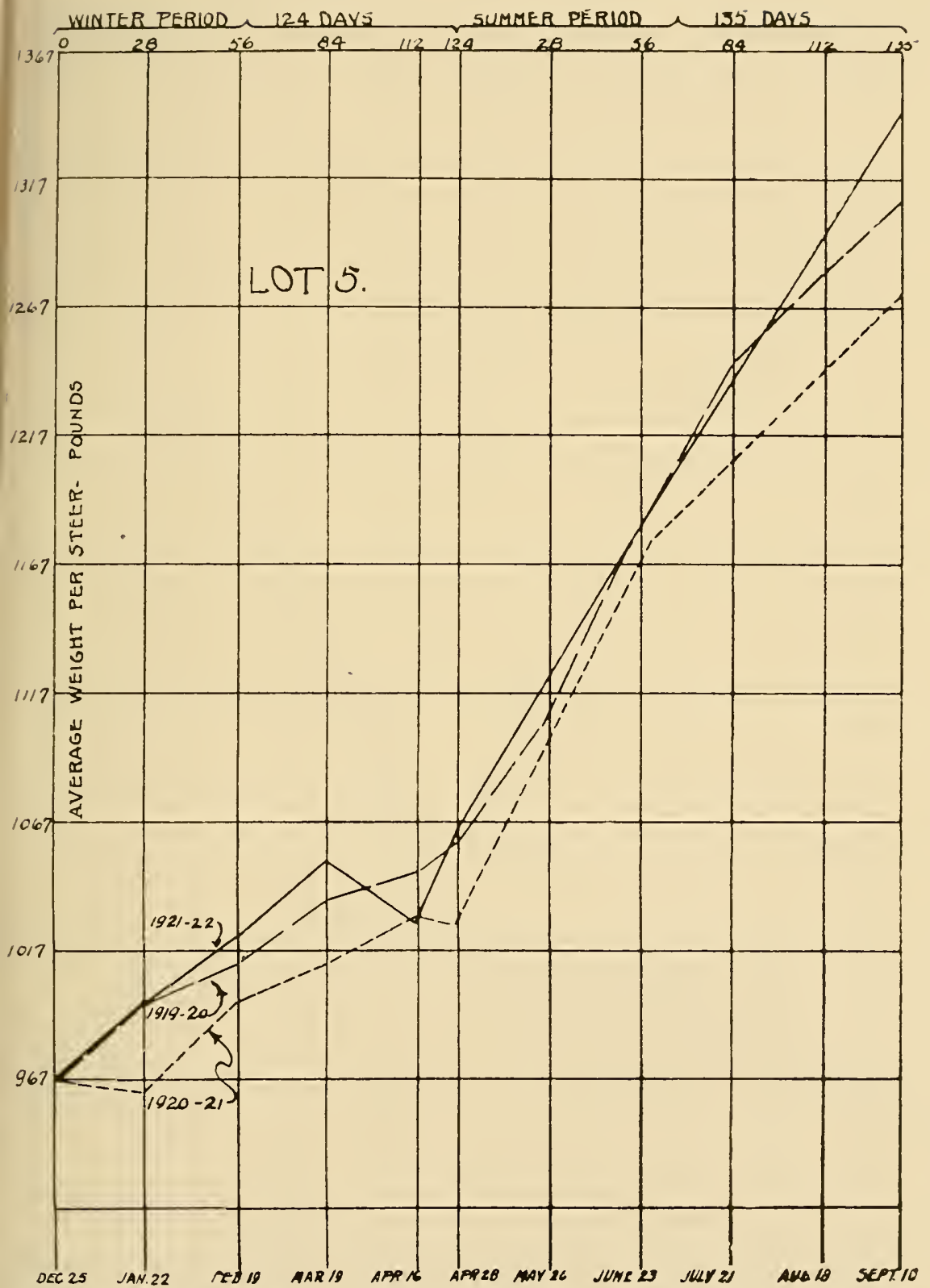

Fig. 6.-Annual Results of Winter and Summer (Grass) Feeding for Lot 5. These Steers Were Fed the Following Average Ration During the Winter: Corn Silage 24.8 Pounds, Wheat Straw 5.8 Pounds, and Cottonseed Meal 1.0 Pounds. 
AVERAGE LENGTH OF FEEDING PERIOD

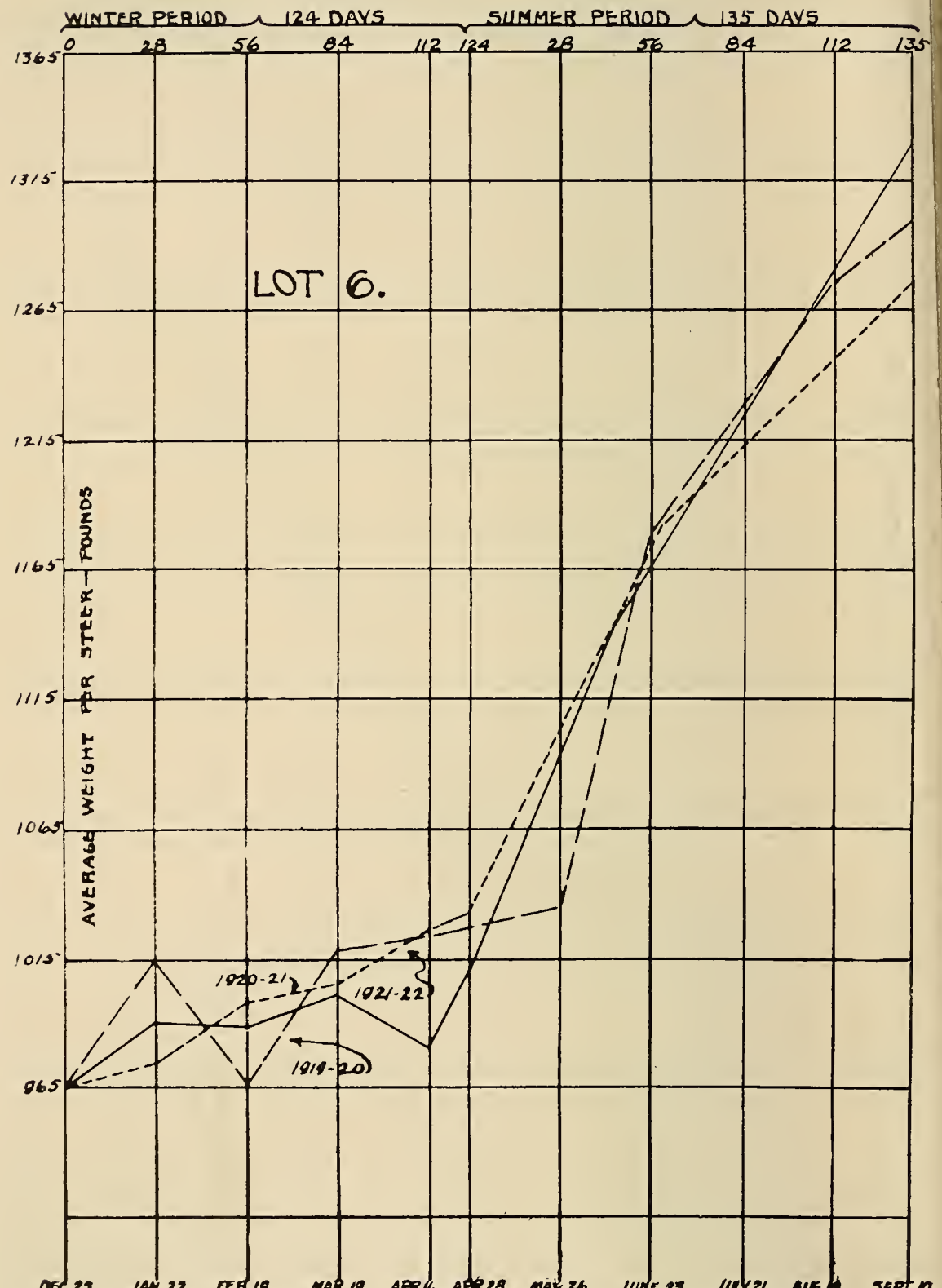

Fig. 7.--Annual Results of Winter and Summer (Grass) Feeding for Lot 6. These Steers Were Fed the Following Average Ration During the Winter: Corn Silage 24.8 Pounds and Mixed Hay 7.3 Pounds. 


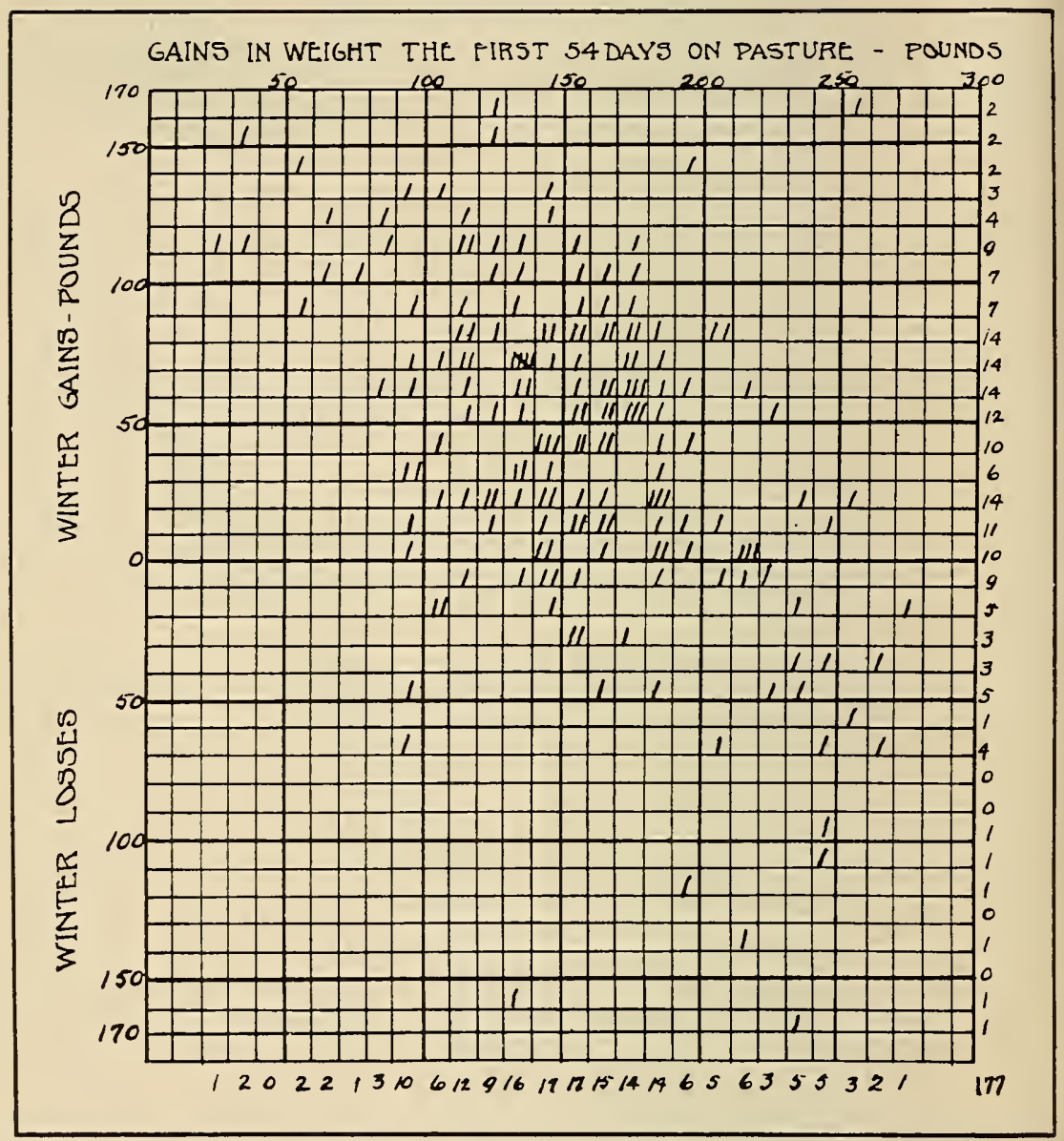

Fig. 9.-Correlation Between the Winter Losses and Gains and the Gains for the First 54 Days (Average for Three Years) on Pasture, Based on the Individual Steers.

Horizontal distance on the charts indicates the number of days that the steers were fed during the three winters and pastured during the three summers. The average date on which each monthly period began is also given. The average length of the total period for the three years was 259 days, of which 124 days were in the winter period, and the remaining 135 in the summer period.

Vertical distance on the charts represents changes in live weights of the steers. The weights corresponding to each of the horizontal 


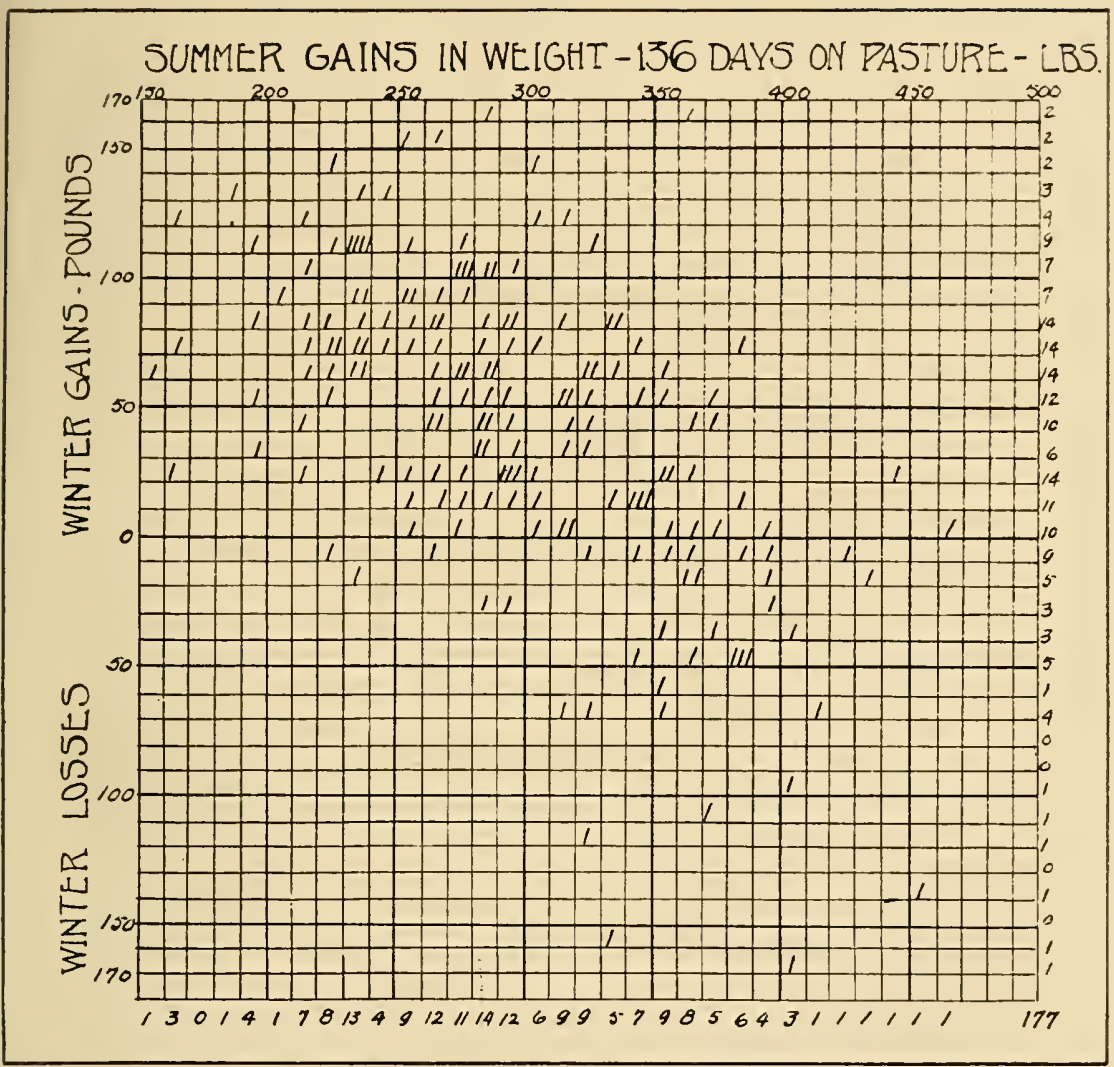

Fig. 10.-Correlation Between the Winter Losses and Gains and the Gains on Pasture the Following Summer, Based on the Individual Steers.

lines are given along the left side of the chart. As the average initial weight of each lot varied from year to year, the average initial weight per steer for three years is used as a basis in each chart for showing the gains made by each lot each year.

Much of the difference caused by the winter feeding was overcome during the summer. On April 28, there was a difference of 95 pounds between the highest and lowest lots; on June 23, 50 pounds; and on September 10, 33 pounds.

\section{Correlations.}

On account of the variations in the average gains of the six lots during the three years, as shown in Table 5, page 14 , the correlations between the winter, summer, midsummer, and total gains of all the 


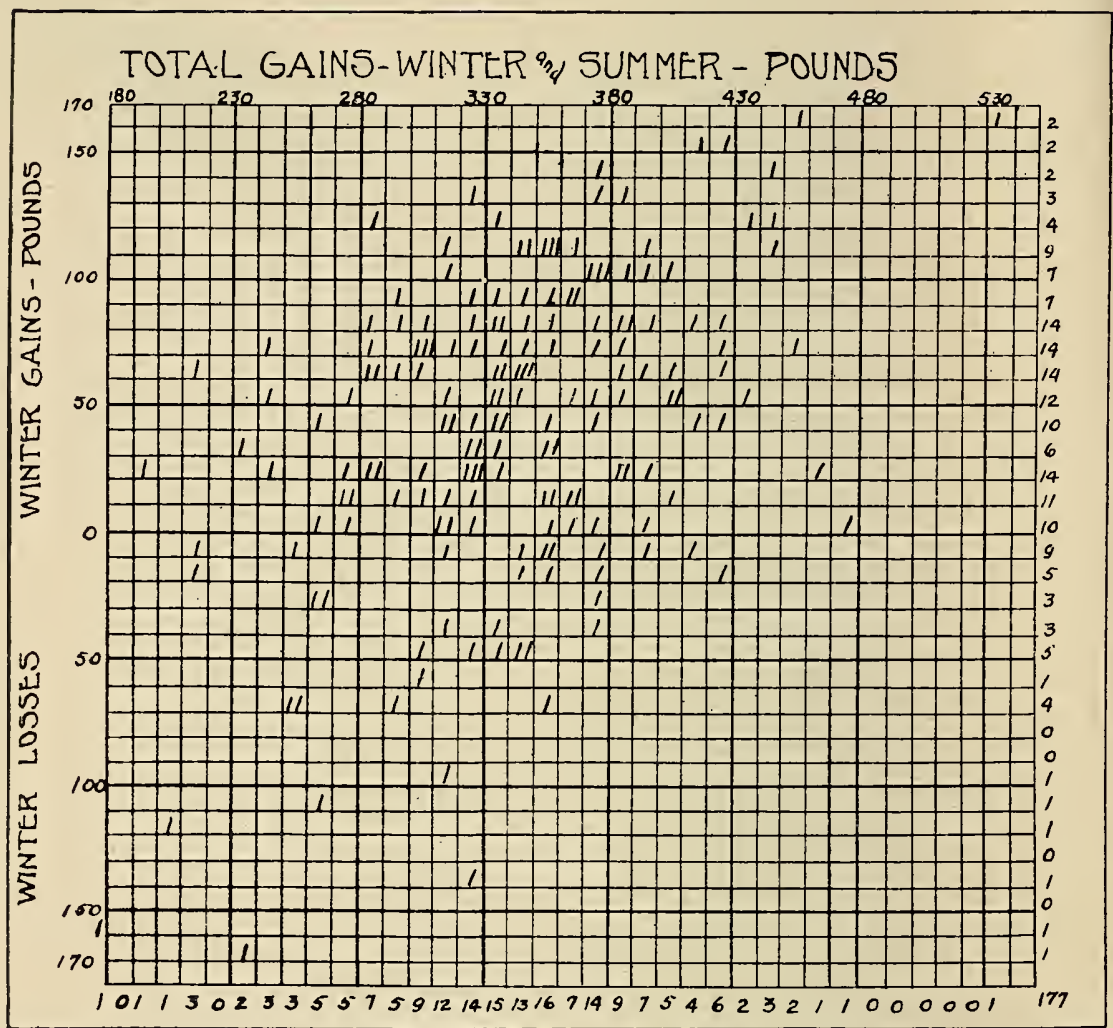

Fig. 11.-Correlation Between the Winter Losses and Gains and the Total Gains for Winter and Summer Periods, Based on the Individual Steers.

steers based on the losses and gains of each steer have been calculated to substantiate the conclusions indicated by the average gains of each lot for three years. Consequently figures $9,10,11$, and 12 show the positions of the individual steers, when they are plotted according to their winter, summer, midsummer, and total variations in weight. Accordingly, the following results have been obtained: 


\begin{tabular}{|c|c|c|c|}
\hline & $\begin{array}{l}\text { Winter Gain } \\
\text { (Pounds) }\end{array}$ & \multicolumn{2}{|c|}{$\begin{array}{l}\text { Summer Gain } \\
\text { (Pounds) }\end{array}$} \\
\hline $\begin{array}{l}\text { Meau } \\
\text { Standard Deviation }\end{array}$ & $\begin{array}{l}44.0 \\
60.1\end{array}$ & \multicolumn{2}{|c|}{$\begin{array}{c}297.7 \\
62.7\end{array}$} \\
\hline & Correlations & & \\
\hline Winter-summer & & -.572 & \pm 0.034 \\
\hline Winter-midsurnmer & & -.480 & \pm 0.038 \\
\hline Winter-total & & +.429 & \pm 0.041 \\
\hline Summer-total & & +.493 & \pm 0.038 \\
\hline & Regressions & & \\
\hline Midsummer/winter & & & $=.616$ \\
\hline Total/winter & & & $=.407$ \\
\hline Total/summeI & & & $=.453$ \\
\hline Summer/winter & & & $=.593$ \\
\hline
\end{tabular}

*The sulu of the mean winter and summer gain is 341.7 while the mean for the total gain is 342.2 , the discrepancy being due in all probability to the gronping of the gains in classes of 10 pounds range.

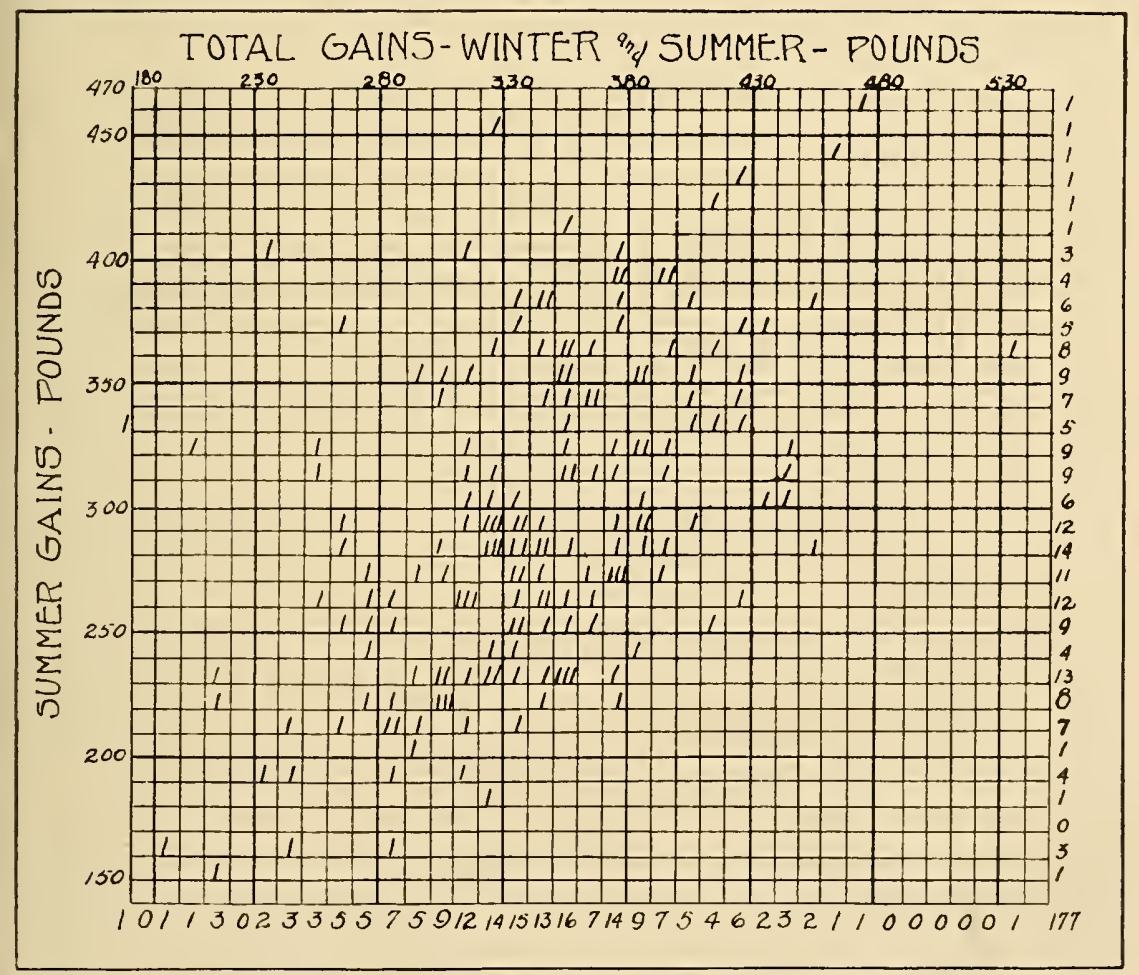

Fig. 12.-Correlation Between the Gains of the Summer Periods and the Total Gains for the Winter and summer Periods, Based on the Individual Steers. 
According to the regressions, 100 pounds advantage in weigh at the end of the winter is reduced to 61.6 pounds after 54 days or grass and to 40.7 pounds after 136 days on grass. In other words during the first 54 days on grass, 38.4 pounds is lost of 100 pound: advantage as compared with 21.3 pounds lost during the rest of the summer period of 82 days, making a total loss of 59.3 pounds for the whole summer period.

\section{COST OF RATIONS FOR WINTERING TWO-YEAR-OLD STEERS}

Whether to purchase steers in the fall and carry them through the winter largely on roughage or to purchase them in the spring after some one else has wintered them is a question which the thoughtful cattle grazier tries to answer. No matter what the answer may be on any particular farm or in any particular section of the country, the fact remains that cattle are generally higher in price and are worth more in the spring just before the grass season cpens than they were at the close of the pasture period the preceding fall. This increase in value is due to the cost of wintering and the dem and for cattle to make use of grass in the spring. In the following discussion the various winter rations are compared to determine which is the cheapest per day, and especially which produced a pound of gain most cheaply. For this purpose it is necessary to fix the price for feeds on the farm. It is felt, however, that this is the most questionable and unsatisfactory part of such experimental work, especially for the last few years, during which unusual fluctuations have occurred in feed prices. On account of these fluctuations and aiso for simplicity in making the various calculations an average of the feed prices for the three vears is used, as follows:

\begin{tabular}{|c|c|}
\hline Corn silage & $\$ 6.00$ \\
\hline Cottonseed meal & 50.00 \\
\hline Mixed hay -- & 18.00 \\
\hline t straw & 6.50 \\
\hline - & 0.70 \\
\hline per day & 0.10 \\
\hline
\end{tabular}


'ABLE 6.-Average Winter Gains or Losses, Summer Gains, Cost of Feed per Steer, and Cost per Pound of Gain.

\begin{tabular}{|c|c|c|c|c|c|c|c|c|}
\hline \multirow[t]{2}{*}{-ot } & \multirow[t]{2}{*}{ Winter Feed } & \multirow[t]{2}{*}{ Season } & \multirow[t]{2}{*}{ 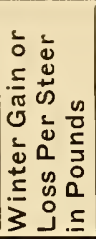 } & \multirow[t]{2}{*}{ 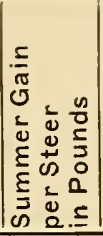 } & Cost of & Feed per & Steer & \multirow[t]{2}{*}{ 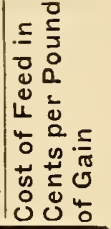 } \\
\hline & & & & & Winter & Summer & Total & \\
\hline \multirow[t]{4}{*}{1} & \multirow{4}{*}{$\begin{array}{l}\text { Mixed hay and } \\
\text { ear corn }\end{array}$} & $1919-20$ & 35 & 307 & $\$ 25.40$ & $\$ 13.60$ & $\$ 39.00$ & $\overline{11.4}$ \\
\hline & & $1920-21$ & & 285 & 24.05 & 12.80 & 36.85 & 10.8 \\
\hline & & 1921-22 & -37 & 344 & 19.19 & 14.10 & 33.29 & 10.8 \\
\hline & & Average| & $18 \mid$ & 312 & 22.88 & 13.50 & 36.38 & 11.1 \\
\hline \multirow[t]{4}{*}{2} & \multirow[t]{4}{*}{ Corn silage } & $1919-20$ & 37 & 286 & 11.43 & 13.60 & 25.03 & 7.7 \\
\hline & & 1920-21 & -54 & 363 & 10.47 & 12.80 & 23.27 & 7.5 \\
\hline & & 1921-22] & -6 & 384 & 10.46 & 14.10 & 24.56 & 6.5 \\
\hline & & Average & -9 & 346 & 10.78 & 13.50 & 24.28 & 7.2 \\
\hline \multirow[t]{4}{*}{3} & \multirow[t]{4}{*}{ Corn silage } & $1919-20$ & 79 & 239 & 15.24 & 13.60 & 28.84 & $\overline{9.1}$ \\
\hline & & $1920-21$ & 46 & 305 & 14.52 & 12.80 & 27.32 & 7.8 \\
\hline & & $1921-22$ & 72 & 306 & 13.43 & 14.10 & 27.32 & 7.8 \\
\hline & & Average & 66 & $283 \mid$ & 14.40 & 13.50 & 27.90 & 8.0 \\
\hline \multirow[t]{4}{*}{4} & \multirow{4}{*}{$\begin{array}{l}\text { Corn silage and } \\
\text { cottonseed meal }\end{array}$} & $1919-20$ & $67 !$ & 297 & 16.19 & 13.60 & 29.79 & 8.2 \\
\hline & & $1920-21$ & 15 & 316 & 15.01 & 12.80 & 27.81 & 8.4 \\
\hline & & 1921-22 & 69 & 322 & 15.65 & 14.10 & 29.75 & 7.6 \\
\hline & & Average & 50 & 312 & 15.62 & 13.50 & 29.12 & 8.0 \\
\hline \multirow[t]{4}{*}{5} & \multirow{4}{*}{$\begin{array}{l}\text { Corn silage, } \\
\text { wheat straw and } \\
\text { cottonseed meal }\end{array}$} & $1919-20$ & 93 & 250 & 15.11 & 13.60 & 28.71 & 8.4 \\
\hline & & 1920-21 & 62 & 245 & 14.53 & 12.80 & 27.33 & 8.9 \\
\hline & & 1921-22 & 97| & 280 & 14.86 & 14.10 & 28.96 & 7.7 \\
\hline & & Average & 86 & 258 & 14.85 & $13.50 \mid$ & 28.35 & 8.2 \\
\hline \multirow[t]{4}{*}{6} & \multirow{4}{*}{$\begin{array}{l}\text { Corn silage and } \\
\text { mixed hay }\end{array}$} & 1919-20 & 63 & 273 & 18.51 & 13.60 & 32.11 & 9.6 \\
\hline & & $1920-21$ & 68 & 243 & 17.78 & 12.80 & 30.58 & 9.8 \\
\hline & & $1921-22$ & 46 & 316 & 15.95 & 14.10 & 30.05 & 8.3 \\
\hline & & Average | & 59 & $277 \mid$ & 17.41 & $13.50 \mid$ & 30.91 & 9.2 \\
\hline
\end{tabular}


When one wishes to determine which ration should be used ir a particular operation, it is suggested that he apply local prices tc the average amounts of the feeds consumed per steer as given in Table 4, page 13.

Cost per Pound of Gain.

Table 6 shows the cost of winter feed and summer pasture, and the cost per pound of total gain. The cost of the winter feed is considerably more than the cost of summer feed, yet the gain is made chiefly in summer. This explains why feeder steers cost so much more in the spring than in the fall. It is considered that the cost of labor and other expenses are balanced by the manure produced.

While the steers of Lot 1 made the least gain during the year, their gain cost the most per pound. Lot 2, which made practically the same gain as Lot 6 , produced their gain at considerably less cost than any other Lot. Lots 3, 4, and 5, which made the greatest gains were next to Lot 2 in cheapness. The cost of gain in Lot 6 was intermediate between that of Lot 1 and of Lots 2, 3, and 5.

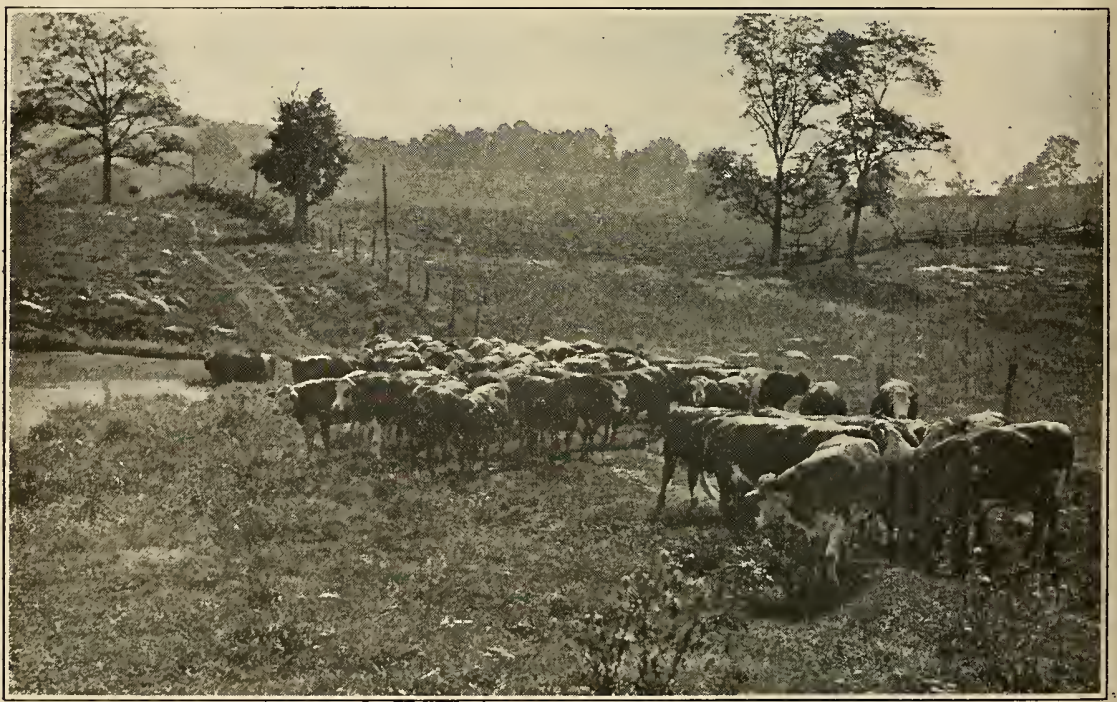

The Six Lots of Steers in September, 1922, at the Lower Corner of Their Pasture. They Are About to be Driven Five Miles to be Loaded and Shipped to Jersey City. 


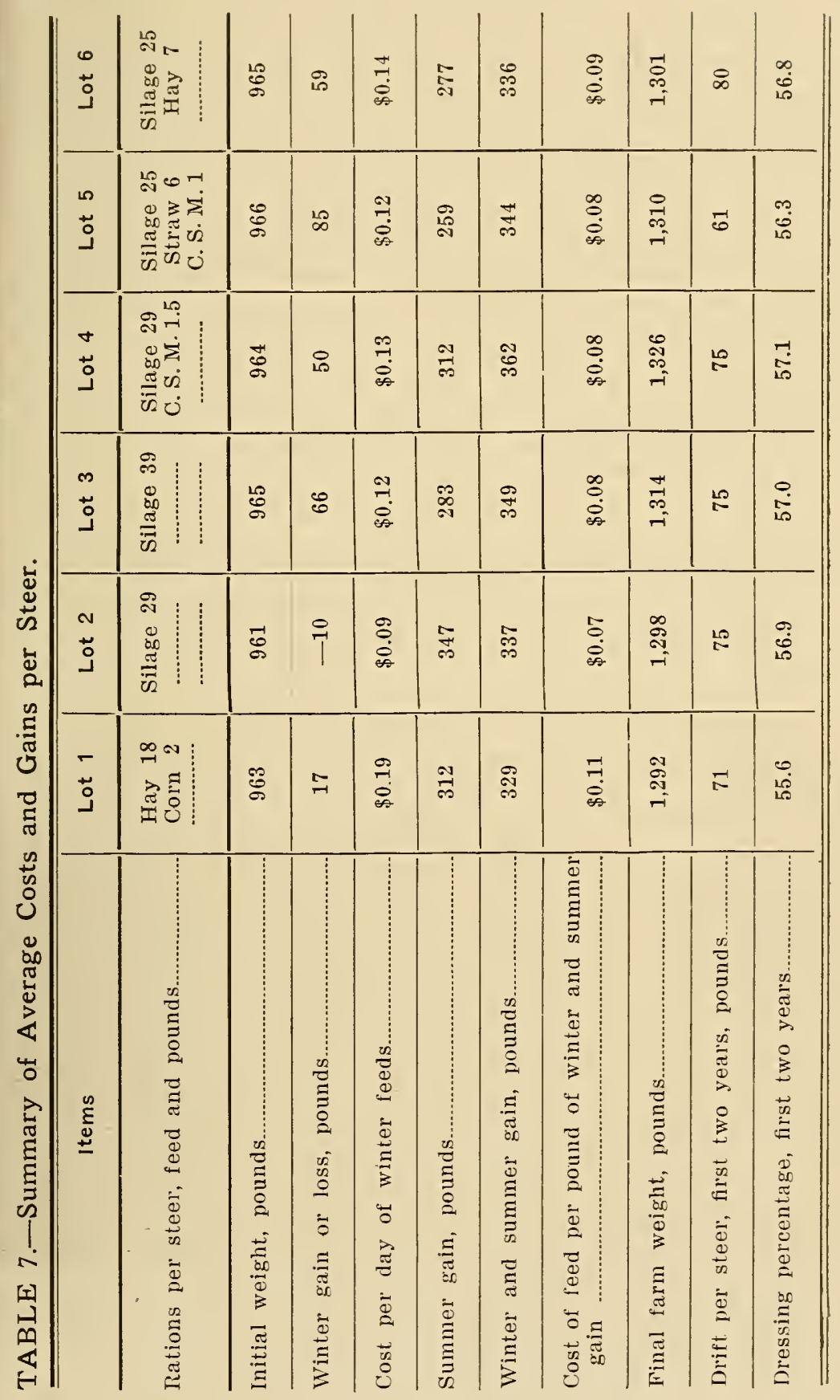




\section{Shrinkage in Transit and Dressing Percentage}

The shrinkage in transit, commonly called "drift" in the Ap. palachian region, and the dressing percentages are given in Table 8 for the first two years. Conditions incident to marketing the cattle prevented obtaining these data at the end of the third summer. The steers were marketed in Jersey City each year. They were shipped either on the same day or on the day after the final farm weigth were taken. The trip to Jersey City usually required about three days, the cattle being unloaded in transit once for feed and water. They were sold and slaughtered soon after reaching market. Variations in shrinkage and dressing percentage of the several lots are not considered to be sufficiently large for drawing conclusions relative to the methods of winter feeding. However, it should be noted that Lot 4, which made the largest gain for the year, dressed highest, and that Lot 1, which made the least gain dressed lowest.

TABLE 8.-Market Weight, Shrinkage in Transit, and Dressing Percentage per Steer for the First and Second Year's Work.

\begin{tabular}{|c|c|c|c|c|c|c|c|c|}
\hline 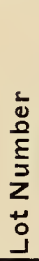 & Winter Feed & 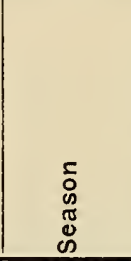 & 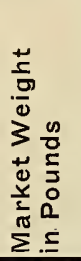 & 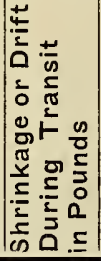 & 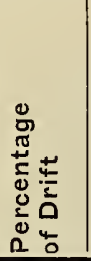 & $\begin{array}{l}\frac{1}{5} \\
0 \\
0 \\
0 \\
3 \\
0 \\
0 \\
0 \\
0 \\
0 \\
0 \\
0 \\
0 \\
0 \\
0 \\
0.5\end{array}$ & 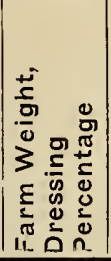 & 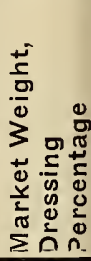 \\
\hline \multirow[t]{2}{*}{1} & \multirow[t]{2}{*}{$\begin{array}{c}\text { Mixed hay and ear } \\
\text { corn }\end{array}$} & $\begin{array}{l}1919-20 \\
1920-21\end{array}$ & $\begin{array}{l}1,203 \\
1,244\end{array}$ & $\begin{array}{l}66 \\
77\end{array}$ & $\begin{array}{l}5.2 \\
5.8\end{array}$ & $\begin{array}{l}673 \\
687\end{array}$ & $\begin{array}{l}53.0 \\
52.0\end{array}$ & $\begin{array}{l}55.9 \\
55.2\end{array}$ \\
\hline & & Average & 1,223 & 71 & 5.5 & 68 & 52.5 & 55.6 \\
\hline \multirow[t]{2}{*}{2} & \multirow[t]{2}{*}{ Corn silage } & $\begin{array}{l}1919-20 \\
1920-21\end{array}$ & $\begin{array}{l}1,174 \\
1,202\end{array}$ & $\begin{array}{l}62 \\
88\end{array}$ & $\begin{array}{l}5.0 \\
6.8\end{array}$ & $\begin{array}{l}668 \\
685\end{array}$ & $\begin{array}{l}54.0 \\
53.1\end{array}$ & $\begin{array}{l}56.9 \\
57.0\end{array}$ \\
\hline & & Average & 1,189 & 75 & 5.9 & 676 & 53.5 & 56.9 \\
\hline \multirow[t]{2}{*}{3} & \multirow[t]{2}{*}{ Corn silage } & $\begin{array}{l}1919-20 \\
1920-21\end{array}$ & $\begin{array}{l}1,187 \\
1,246\end{array}$ & $\begin{array}{l}59 \\
92\end{array}$ & $\begin{array}{l}4.7 \\
6.9\end{array}$ & $\begin{array}{l}677 \\
709\end{array}$ & $\begin{array}{l}54.3 \\
53.0\end{array}$ & $\begin{array}{l}57.0 \\
56.9\end{array}$ \\
\hline & & Average & 1,216 & .75 & 5.8 & 693 & 53.6 & 57.0 \\
\hline \multirow[t]{2}{*}{4} & \multirow[t]{2}{*}{$\mid \begin{array}{cl}\text { Corn silage and } \\
\text { cottonseed meal }\end{array}$} & $\begin{array}{l}1919-20 \\
1920-21\end{array}$ & $\begin{array}{l}1,225 \\
1,229\end{array}$ & $\begin{array}{l}66 \\
85\end{array}$ & $\begin{array}{l}5.1 \\
6.5\end{array}$ & $\begin{array}{l}704 \\
699\end{array}$ & $\begin{array}{l}54.5 \\
53.2\end{array}$ & $\begin{array}{l}57.4 \\
56.9\end{array}$ \\
\hline & & Average & 1,227 & 75 & 5.8 & 701 & 53.8 & 57.1 \\
\hline \multirow[t]{2}{*}{5} & \multirow{2}{*}{$\begin{array}{l}\text { Corn silage, wheat } \\
\text { straw, and cotton- } \\
\text { seed meal }\end{array}$} & $\begin{array}{l}1919-20 \\
1920-21\end{array}$ & $\begin{array}{l}1,223 \\
1,215\end{array}$ & $\begin{array}{l}47 \\
79\end{array}$ & $\begin{array}{l}3.7 \\
6.1\end{array}$ & $\begin{array}{l}681 \\
694\end{array}$ & $\begin{array}{l}53.6 \\
53.6\end{array}$ & $\begin{array}{l}55.7 \\
57.1\end{array}$ \\
\hline & & Average & 1,220 & 61 & 4.9 & 687 & 53.6 & 56.3 \\
\hline \multirow[t]{2}{*}{6} & \multirow[t]{2}{*}{$\begin{array}{l}\text { Corn silage and } \\
\text { mixed hay }\end{array}$} & $\begin{array}{l}1919-20 \\
1920-21\end{array}$ & $\begin{array}{l}1,187 \\
1,211\end{array}$ & $\begin{array}{l}77 \\
84\end{array}$ & $\begin{array}{l}6.1 \\
6.5\end{array}$ & $\begin{array}{l}697 \\
684\end{array}$ & $\begin{array}{l}53.7 \\
52.8\end{array}$ & $\begin{array}{l}57.2 \\
56.5\end{array}$ \\
\hline & & Average & 1,199 & 80 & 6.3 & 681 & 53.2 & 56.8 \\
\hline
\end{tabular}




\section{CONCLUSIONS}

1.- (in the whole the steers which made larger winter gains also ade larger total gains for the year, when fattened on grass the llowing summer (correlation +.43 ).

2.- The steers which made only slight gains or lost in weight uring the winter made greater summer gains on pasture than steers hich made larger winter gains (correlation between winter and .mmer gains -.57).

3.-Consequently differences in weight of steers at the end of ie winter, due to rations fed, are gradually minimized during the me of summer fattening on grass. (an advantage of 100 pounds at ze end of winter falls to one of only 41 pounds after 136 days on rass).

4.- Since differences in weight due to winter feeding are gradally minimized but not wholly overcome during the summer season f fattening on grass, it is important that cattle to be marketed early hould gain considerable more weight during the winter than if they re to be marketed late (an advantage of 100 pounds at the end of vinter falls to one of 62 pounds after 54 days on grass).

5.-There is so little difference between the gains made by the ;teers in the different lots at the end of the summer grazing period hat any conclusion as to the best winter ration must take into conideration the cost of the ration.

6.- Succulent rations of silage alone; or silage, cottonseed meal, Ind straw; or silage and mixed hay, as used in this experiment, are :heaper and produce greater gains for the year than a dry ration of nixed hay and ear corn. 



\section{HECKMAN \\ BINDERY INC.}

\section{JUNE 99}

N MANCHESTER INDIANA 46962 
